\title{
Recent advances in the study of mercury methylation in aquatic systems
}

\author{
Avnee R. Paranjape ${ }^{a}$ and Britt D. Hall ${ }^{\text {a }}$ \\ ${ }^{a}$ Department of Biology, University of Regina, 3737 Wascana Parkway, Regina, SK S4S 0A2, Canada \\ *britt.hall@uregina.ca
}

\begin{abstract}
With increasing input of neurotoxic mercury to environments as a result of anthropogenic activity, it has become imperative to examine how mercury may enter biotic systems through its methylation to bioavailable forms in aquatic environments. Recent development of stable isotope-based methods in methylation studies has enabled a better understanding of the factors controlling methylation in aquatic systems. In addition, the identification and tracking of the $h g c A B$ gene cluster, which is necessary for methylation, has broadened the range of known methylators and methylation-conducive environments. Study of abiotic factors in methylation with new molecular methods (the use of stable isotopes and genomic methods) has helped elucidate the confounding influences of many environmental factors, as these methods enable the examination of their direct effects instead of merely correlative observations. Such developments will be helpful in the finer characterization of mercury biogeochemical cycles, which will enable better predictions of the potential effects of climate change on mercury methylation in aquatic systems and, by extension, the threat this may pose to biota.
\end{abstract}

Key words: mercury, methylation, methylmercury, biogeochemistry, aquatic systems, $h g c A B$ gene cluster, stable isotopes, environmental controls, climate change

\section{OPEN ACCESS}

Citation: Paranjape AR and Hall BD. 2017. Recent advances in the study of mercury methylation in aquatic systems. FACETS 2: 85-| 19. doi: | 0.1 | 39/facets-20 | 6-0027

Editor: John Smol

Received: June 6, 2016

Accepted: November 15, 2016

Published: February 7, 2017

Copyright: (C) 2017 Paranjape and Hall. This work is licensed under a Creative Commons Attribution 4.0 International License (CC BY 4.0), which permits unrestricted use, distribution, and reproduction in any medium, provided the original author(s) and source are credited.

Published by: Canadian Science Publishing

\section{Introduction}

Mercury $(\mathrm{Hg})$ is a highly toxic heavy metal present at naturally low concentrations in most environmental systems (Ullrich et al. 2001). Decades of industrial activity such as manufacturing, wastewater treatment plants, and coal burning have resulted in emissions of $\mathrm{Hg}$ to concentrations above background levels (Driscoll et al. 2007; Weiss-Penzias et al. 2016; Zhang et al. 2016). Because of its accumulation through aquatic food chains, $\mathrm{Hg}$ can be dangerous to organisms even at relatively low concentrations (Boening 2000; Driscoll et al. 2007). Compared with inorganic forms, organic forms of $\mathrm{Hg}$ are particularly toxic (Boening 2000; Wiener et al. 2003; Hightower 2009). The methylated form of mercury, monomethylmercury (often simplified to methylmercury; $\mathrm{MeHg}$ ), is a particularly problematic neurotoxin (Ullrich et al. 2001; Driscoll et al. 2007). This highly bioavailable form of $\mathrm{Hg}$ is capable of bioaccumulating to toxic levels at higher trophic levels (Driscoll et al. 2007). In humans, the results of mercury poisoning can be disastrous, including the inhibition of endocrine function (Tan et al. 2009), cardiac effects such as hypertension (Grandjean et al. 2004) and atherosclerosis (Tan et al. 2009), and in severe cases such as in Minamata and Niigata (Japan; Normile 2013), and the Wabigoon-English River system (Ontario, Canada; Takaoka et al. 2014), mercury poisoning can result in fetal death, neurological disorders resembling cerebral palsy, deafness, and visual impairment (Tsubaki and Irukayama 1977). 
In the decades since the mercury poisoning of these fishery-reliant communities, research into both understanding the environmental mercury cycle and the development of technologies designed to reduce the release of mercury to ecosystems have culminated in the recent signing of the global treaty, the Minamata Convention on Mercury (Eriksen and Perrez 2014). The genesis of this convention was the 2003 United Nations Environment Programme General Council (UNEP GC), where the Global Mercury Assessment study was presented showing significant global risks to both human health and the environment, prompting calls for action. However, several countries, including the USA, Australia, and Canada, initially opposed a legally binding agreement on reducing anthropogenic mercury sources (Eriksen and Perrez 2014). The agreement gained greater support by 2009 following the election of the Obama administration, which ended the US's opposition to a legally binding instrument, thereby encouraging the UNEP GC to begin negotiations for the convention. The Minamata Convention was formally signed and adopted in October 2013 (Eriksen and Perrez 2014), and contains various provisions targeting key anthropogenic Hg sources such as manufacturing, emissions from power plants, the use of $\mathrm{Hg}$ in products, and the management of Hg-contaminated waste (Evers et al. 2016). If properly implemented, the Minamata Convention is expected to continue to reduce anthropogenic emissions of $\mathrm{Hg}$, which have declined by $30 \%$ between 1990 and 2010, with significant emission reduction in North America and Europe in particular (Zhang et al. 2016).

However, despite the successful reduction of $\mathrm{Hg}$ in emissions since 1990 (Zhang et al. 2016), there are a number of important issues that make $\mathrm{Hg}$ a continuing concern. The potential of increased emissions in Asia as well as issues surrounding legacy deposition continue to provide impetus for more fully understanding $\mathrm{Hg}$ cycling in environments. In addition, changes in the complex $\mathrm{Hg}$ cycling will result from increasing rates of anthropogenic climate change. Thus, the crucial importance of understanding $\mathrm{Hg}$ methylation once it enters an aquatic system and the conditions that favour the production of $\mathrm{MeHg}$, allowing its subsequent uptake by biota, continue to be important research subjects.

The objective of this review is to examine key advances in the study of factors that impact and control methylation (particularly bacterial methylation) over the last 10 years. Although there have been several recent studies that focused on contaminated sites (Duran et al. 2008; Gray and Hines 2009; Huguet et al. 2010; Avramescu et al. 2011; Hines et al. 2012; Marvin-DiPasquale et al. 2014; Windham-Myers et al. 2014a, 2014b, 2014c; Eckley et al. 2015; Figueiredo et al. 2016; Liu et al. 2016), these are beyond the scope of this paper; this review focuses exclusively on non-polluted aquatic systems. Recent reviews regarding both $\mathrm{Hg}$ methylation and demethylation focused on assessing the bioavailability of particular $\mathrm{Hg}$ species and the use of stable isotope techniques in methylation studies (Li and Cai 2013), the molecular mechanisms of mercury uptake and methylation (Hsu-Kim et al. 2013b), and Hg cycling in Arctic (Douglas et al. 2012; Braune et al. 2015) and coastal marine and estuarine (Merritt and Amirbahman 2009) systems. In contrast, our review focuses on advances in the study of biotic methylation, the diverse aquatic environments in which methylation has been identified, and the advancement of understanding abiotic conditions favourable to microbial methylation. In addition, we provide a brief analysis of the impacts of a changing climate on $\mathrm{Hg}$ methylation.

\section{Why is net methylmercury production important and how it is determined?}

Bioaccumulation of $\mathrm{MeHg}$ depends on both the methylation of inorganic mercury and its transfer from sites of methylation to organisms (Boening 2000). Natural demethylation processes occur simultaneously through either the metabolic activity of many microbial species (Oremland et al. 1995; Marvin-DiPasquale et al. 2000) or abiotic photodegradation (Sellers et al. 1996; Hammerschmidt and Fitzgerald 2006a; Lehnherr and St. Louis 2009; Bittrich et al. 2011), and it is the net result of these 
opposing reactions that regulates concentrations of organic $\mathrm{Hg}$ available for uptake (Boening 2000; Ullrich et al. 2001). Abiotic methylation may occur if sufficient methyl donors are present; conditions that may be afforded by an environment rich in organic material (Nagase et al. 1982). However, abiotic methylation is generally thought to be of little importance in most aquatic systems (Ullrich et al. 2001). Another possible avenue of abiotic methylation is photomethylation under UV radiation-a process that has been identified in vitro (Akagi et al. 1974; Hayashi et al. 1977), but the exact mechanism of which remains unclear (Chen et al. 2015). The noted simultaneous production and degradation of $\mathrm{MeHg}$ may result in $\mathrm{MeHg}$ in sediments being in steady-state (Pak and Bartha 1998); however, levels in biota may be much higher due to bioaccumulation (Ullrich et al. 2001).

The majority of $\mathrm{MeHg}$ production occurring in aquatic systems is via biotic mechanisms, namely, bacterial methylation. There are several parameters that may be used as a proxy to measure methylation. The presence of methylation can be inferred from the activity of methylating bacteria, measurements of elevated concentrations of $\mathrm{MeHg}$, changes in $\mathrm{Hg}$ mass balance budgets, and the proportion of the total $\mathrm{Hg}$ that is in the methylated form $(\% \mathrm{MeHg})$. In the past, experimental and descriptive methods were used to assess correlative relationships among $\mathrm{MeHg}$ concentrations and environmental controls. However, within the last decade, stable isotopes have been used to measure potential methylation rates $\left(K_{\text {meth }}\right)$ (Hintelmann et al. 2000) to address questions surrounding rates of, and factors controlling, methylation in aquatic systems (Table 1). Throughout this review, advances in our understanding of MeHg production using this new technique illustrate its value. For example, Jonsson et al. (2012, 2014) used potential methylate measurement in estuarine systems to determine that the input of allochthonous $\mathrm{MeHg}$ from terrestrial and atmospheric sources is a substantially greater source than existing sediment $\mathrm{Hg}$ pools to aquatic organisms. Another aspect of this newer work is to examine rates of $\mathrm{MeHg}$ production in novel environments. Measurements of $K_{\text {meth }}$ on the continuum of the saline gradient of Great Salt Lake, Utah, USA has shown that methylation rates are similar to other systems; but more importantly, that seasonal decreases in potential methylation rates in the deep brine layer of the lake corresponds to reduced $\mathrm{Hg}$ burdens of aquatic invertebrates, which have been implemented as possible vectors of $\mathrm{Hg}$ to avian species using the lake (Johnson et al. 2015). Potential methylation rates in prairie wetlands are similar to other systems, despite elevated concentrations of $\mathrm{MeHg}$ in water (Hoggarth et al. 2015), suggesting that the rates of other processes such as demethylation play a proportionally lesser role in these systems compared with others. This stable isotope technique has also been used to test potential mitigation strategies. Bussan et al. (2016) showed that potential methylation rates decreased in sediments amended with activated carbon and biochar, suggesting that adding these materials to contaminated sediments may decrease $\mathrm{Hg}$ transfer to aquatic organisms. A similar method of using stable $\mathrm{Hg}$ isotopic tracers to determine potential microbial demethylation rates $\left(K_{\text {demeth }}\right)$ has been used much less frequently due to large errors in differentiating the loss of the tracer isotope from low concentrations of ambient mercury in the sediment. As a result, demethylation rates measured using these techniques are most useful in studies of systems in which the details of mercury cycling are well-characterized.

These short-term measurements of potential rates of methylation and demethylation have been found to be unrelated to gross measures of long-term MeHg accumulation (Drott et al. 2008; Johnson et al. 2016). This suggests that these snapshot measurements may not be valuable in determining long-term process measurements. However, significant positive correlations have been found between $K_{\text {meth }}$ and $\% \mathrm{MeHg}$ in many environments (Drott et al. 2008), and \% MeHg values in boreal wetlands tracked the ratio of $K_{\text {meth }}$ to $K_{\text {demeth }}$ (Tjerngren et al. 2012a), suggesting that if both rates are measured, steady state net $\mathrm{MeHg}$ production rates can be estimated. Very recently, measurements of potential rates have been replaced with measurements of the genetic potential of the microbial community (e.g., Gionfriddo et al. 2016) due to the recent discovery of a gene cluster responsible for mercury methylation (see below), and developments in this area will be useful in addressing many of the questions previously addressed using the measurements of potential rates. 
Table 1. Methylation $\left(K_{\text {meth }} \cdot \mathrm{d}^{-1}\right)$ and demethylation $\left(K_{\text {demeth }} \cdot h^{-1}\right)$ potentials, methylmercury $\left(\mathrm{MeHg}\right.$ ng.g ${ }^{-1}$ dry weight), and percent of total mercury as methylmercury $(\% \mathrm{MeHg})$ for various types of freshwater, estuarine, and marine systems.

\begin{tabular}{|c|c|c|c|c|c|c|}
\hline Location & Type of system & $K_{\text {meth }}\left(\mathrm{d}^{-1}\right)$ & $K_{\text {demeth }}\left(h^{-1}\right)$ & $\begin{array}{l}\text { Sediment ambient } \\
\mathrm{MeHg}\left(\mathrm{ng} \cdot \mathrm{g}^{-1}\right)\end{array}$ & $\begin{array}{l}\text { Sediment } \\
\% \mathrm{MeHg}\end{array}$ & Reference \\
\hline
\end{tabular}

\section{Freshwater}

\begin{tabular}{|c|c|c|c|c|c|c|}
\hline Florida Everglades & Wetlands & $0-0.12$ & na & $\sim 0.1-4.5$ & $0.1-1.7$ & Gilmour et al. (1998) \\
\hline Ontario, Canada & Lake sediments & $0.001-0.016$ & $0.016-0.022$ & $0.43-6.9$ & $0.14-4.6$ & Hintelmann et al. (2000) \\
\hline $\begin{array}{r}\text { Yolo Bypass } \\
\text { California }\end{array}$ & Wetlands & $0.0003-1.3$ & na & $0.53-6.17$ & $0.31-3.88$ & $\begin{array}{l}\text { M. Marvin-DiPasquale } \\
\text { (personal } \\
\text { communication, 2012); } \\
\text { Windham-Myers et al. } \\
(2009)\end{array}$ \\
\hline Boreal Sweden & $\begin{array}{l}\text { Wetlands of different } \\
\text { nutrient status }\end{array}$ & $0.0014-0.01$ & Negligible-0.007 & $3.5-21$ & $2.3-17$ & $\begin{array}{l}\text { Tjerngren et al. (2012a, } \\
2012 b)\end{array}$ \\
\hline Ängessjön, Sweden & Lake sediments & $0.002-0.066$ & $0.0016-0.028$ & na & $0.4-0.9$ & Tjerngren et al. (2012a) \\
\hline High Arctic & Wetlands & $0.04-0.16$ & $0.021-0.354$ & $0.6-18.5$ & $1.2-12$ & Lehnherr et al. (2012) \\
\hline $\begin{array}{l}\text { Northern Great } \\
\text { Plains, } \\
\text { Saskatchewan }\end{array}$ & Prairie wetlands & $0.02-0.17$ & na & $0.18-2.1$ & $0.6-4.8$ & Hoggarth et al. (2015) \\
\hline $\begin{array}{l}\text { Northeastern } \\
\text { Minnesota }\end{array}$ & $\begin{array}{l}\text { Non-sulfate impacted } \\
\text { wetlands }\end{array}$ & $<0.01-0.32$ & $<0.005-0.07$ & $\sim 6-15$ & $\sim 6-15$ & Johnson et al. (2016) \\
\hline $\begin{array}{l}\text { Northeastern } \\
\text { Minnesota }\end{array}$ & $\begin{array}{l}\text { Sulfate impacted } \\
\text { wetlands }\end{array}$ & $<0.01-0.33$ & $<0.005-0.10$ & $\sim 5-13$ & $\sim 7-12$ & Johnson et al. (2016) \\
\hline $\begin{array}{l}\text { Northeastern } \\
\text { Minnesota }\end{array}$ & $\begin{array}{l}\text { Non-sulfate impacted } \\
\text { lake sediments }\end{array}$ & $0.01-0.31$ & $<0.005-0.11$ & na & na & $\begin{array}{l}\text { N. Johnson (personal } \\
\text { communication, 2016); } \\
\text { Bailey et al. (in review) }\end{array}$ \\
\hline $\begin{array}{l}\text { Northeastern } \\
\text { Minnesota }\end{array}$ & $\begin{array}{l}\text { Sulfate impacted lake } \\
\text { sediments }\end{array}$ & $<0.01-0.09$ & $<0.005-0.15$ & na & na & $\begin{array}{l}\text { N. Johnson (personal } \\
\text { communication, 2016); } \\
\text { Bailey et al. (in review) }\end{array}$ \\
\hline
\end{tabular}

\section{Estuarine and marine}

\begin{tabular}{|c|c|c|c|c|c|c|}
\hline Long Island Sound & Marine sediments & $0.014-0.082$ & na & $0.2-3.2$ & $0.4-1.1$ & $\begin{array}{l}\text { Hammerschmidt and } \\
\text { Fitzgerald (2004) }\end{array}$ \\
\hline $\begin{array}{l}\text { New England coastal } \\
\text { shelf }\end{array}$ & Marine sediments & $0.02-0.21$ & na & $0.1-3.3$ & $0.4-1$ & $\begin{array}{l}\text { Hammerschmidt and } \\
\text { Fitzgerald }(2006 b)\end{array}$ \\
\hline $\begin{array}{l}\text { Kirkpatrick Marsh, } \\
\text { Rhode River, } \\
\text { Maryland }\end{array}$ & Estuarine marsh soil & $0.002-0.07$ & na & $\sim 110-150$ & $0.2-4.6$ & $\begin{array}{l}\text { Mitchell and Gilmour } \\
\text { (2008) }\end{array}$ \\
\hline $\begin{array}{l}\text { San Francisco Bay } \\
\text { Delta, California }\end{array}$ & Estuarine sediments & $0.002-0.122$ & na & $0.6-3.7$ & $0.1-1.4$ & $\begin{array}{l}\text { Windham-Myers et al. } \\
\text { (2009) }\end{array}$ \\
\hline $\begin{array}{l}\text { Öre River estuary, } \\
\text { Sweden }\end{array}$ & Estuarine sediments & 0.8 & $0.002-0.083$ & $\sim 0.1-13$ & na & $\begin{array}{l}\text { Lambertsson and Nilsson } \\
\text { (2006) }\end{array}$ \\
\hline $\begin{array}{l}\text { Mid-Atlantic } \\
\text { continental shelf }\end{array}$ & Marine sediment & $0.002-0.053$ & $0.02-0.04$ & $0.008-0.096$ & $0.7-1.72$ & Hollweg et al. (2010) \\
\hline Adour River, France & Estuarine sediment & 0.03 & 0.004 & 2.2 & 0.9 & $\begin{array}{l}\text { Martín-Doimeadios et al. } \\
\text { (2004) }\end{array}$ \\
\hline
\end{tabular}


Table 1. (concluded)

\begin{tabular}{|c|c|c|c|c|c|c|}
\hline Location & Type of system & $K_{\text {meth }}\left(d^{-1}\right)$ & $K_{\text {demeth }}\left(h^{-1}\right)$ & $\begin{array}{l}\text { Sediment ambient } \\
\mathrm{MeHg}\left(\mathbf{n g} \cdot \mathbf{g}^{-1}\right)\end{array}$ & $\begin{array}{l}\text { Sediment } \\
\% \mathrm{MeHg}\end{array}$ & Reference \\
\hline $\begin{array}{l}\text { San Francisco Bay } \\
\text { Delta, California }\end{array}$ & Estuarine sediment & $<0.0003-0.0049$ & $0.006-0.009$ & na & na & $\begin{array}{l}\text { Marvin-DiPasquale et al. } \\
\quad(2003)\end{array}$ \\
\hline $\begin{array}{l}\text { Bay of Fundy, } \\
\text { Minnesota, } \\
\text { New Brunswick }\end{array}$ & Estuarine sediment & $0-1.2$ & $0.39-0.1 .38$ & 1.6 & 0.20 & Heyes et al. (2006) \\
\hline $\begin{array}{l}\text { Patuxent River, } \\
\text { Maryland }\end{array}$ & Estuarine sediment & $0-0.276$ & na & 0.098 & 0.23 & Heyes et al. (2006) \\
\hline $\begin{array}{l}\text { Hudson River, } \\
\text { New York }\end{array}$ & Estuarine sediment & $0.004-0.43$ & $0.09-1.59$ & 0.22 & 0.70 & Heyes et al. (2006) \\
\hline $\begin{array}{l}\text { Long Island Sound, } \\
\text { USA }\end{array}$ & Estuarine sediment & $0.014-0.082$ & na & $0.20-3.20$ & $0.41-1.05$ & $\begin{array}{l}\text { Hammerschmidt and } \\
\text { Fitzgerald (2004) }\end{array}$ \\
\hline Gulf of Mexico & Marine sediments & $0.02-0.19$ & $1.6-2.6$ & $0.016-0.28$ & $0.04-1.1$ & Liu et al. (2015) \\
\hline \multicolumn{7}{|l|}{ Salt lakes } \\
\hline Great Salt Lake & $\begin{array}{l}\text { Deep brine layer } \\
\text { (DBL) water }\end{array}$ & $\begin{array}{c}0.0000012 \\
-0.0011\end{array}$ & Negligible & na & na & Johnson et al. (2015) \\
\hline Great Salt Lake & $\begin{array}{l}\text { Sediment slurry below } \\
\text { DBL }\end{array}$ & $\begin{array}{c}0.0000012 \\
-0.0031\end{array}$ & Negligible & $0.43-1.60$ & $31.6-242.8$ & Johnson et al. (2015) \\
\hline Great Salt Lake & $\begin{array}{l}\text { Freshwater influenced } \\
\text { bays }\end{array}$ & $\begin{array}{c}0.0000014 \\
-0.0011\end{array}$ & na & $0.01-0.41$ & $5.9-250.5$ & Johnson et al. (2015) \\
\hline \multicolumn{7}{|l|}{ Laboratory } \\
\hline $\begin{array}{l}\text { Intertidal region } \\
\text { surrounding } \\
\text { University of } \\
\text { Connecticut } \\
\text { Avery Point } \\
\text { campus }\end{array}$ & $\begin{array}{l}\text { Laboratory generated } \\
\text { marine snow }\end{array}$ & $<$ MDL-0.02 & $<$ MDL-0.0125 & na & na & Ortiz et al. (2015) \\
\hline $\begin{array}{l}\text { Öre River estuary, } \\
\text { Sweden }\end{array}$ & $\begin{array}{l}\text { Estuarine sediment } \\
\text { amended with } \\
\mathrm{N} \text { and } \mathrm{P}\end{array}$ & $\sim 0.03-0.045$ & $\sim 0.3-0.43$ & 0.28 & 0.72 & Liem-Nguyen et al. (2016) \\
\hline Oxford, Mississippi & $\begin{array}{l}\text { Freshwater sediments } \\
\text { amended with } \\
\text { activated carbon } \\
\text { and biochar }\end{array}$ & $0.00031-0.00366$ & $0.002-0.0038$ & na & na & Bussan et al. (2016) \\
\hline
\end{tabular}

Note: na, not available; MDL, method detection limit.

\section{What methylates and how can we use this information going forward?}

While methylation may occur abiotically in some environments (Celo et al. 2006; Eckley and Hintelmann 2006; Monperrus et al. 2007a; Perrot et al. 2013), biotic methylation by microbes is the primary source of $\mathrm{MeHg}$ in aquatic environments. Sulfate-reducing bacteria (SRB) were the first organisms identified as the primary bacteria responsible for methylation using 
SRB inhibitors (Compeau and Bartha 1985; Gilmour and Henry 1991; Kerry et al. 1991; Gilmour et al. 1992). It is important to note that not all SRB can methylate; therefore, the activity of all SRB is not an ideal indicator for methylation (King et al. 1999; Heyes et al. 2006). In addition, some SRB may be more effective methylators than others. For example, SRB that use acetate as a carbon source have been found to methylate $\mathrm{Hg}$ at equivalent or higher rates than those that do not use acetate (King et al. 2000; Ekstrom et al. 2003). Particular strains of SRB that are capable of methylation include Desulfovibrio (Choi and Bartha 1993; Choi et al. 1994) and identified more recently, 10 of 14 strains in the Desulfovibrio, Desulfotomaculum, and Desulfobulbus genera (Kaschak et al. 2014).

While SRB are important, they are not the sole methylators identified in aquatic environments. In periphyton, sulfate reduction inhibitors were found to have only a partial effect on methylation potential (Achá et al. 2011), indicating the presence of other methylators in the microbial community. In fact, Bravo et al. (2015) found that SRB were not the primary methylators in sewage treatment plants, though specific identification of the methylators was not possible. Correia et al. (2012) asserted that methylation depends on complex interactions among microorganisms, including prokaryotes, algae, fungi, and methanogens, suggesting that syntrophy may have a role in methylation. Iron-reducing bacteria (IRB) have also been implicated in methylation (Yu et al. 2012). In specific tests of the methylating capacity of dissimilatory IRB, it was found that Geobacter sulfurreducens produced $\mathrm{MeHg}$ through an unknown mechanism, whereas Shewanella oneidensis did not (Si et al. 2015). While the reduction of $\mathrm{Fe}(\mathrm{III})$ can stimulate $\mathrm{MeHg}$ formation, higher concentrations of $\mathrm{Fe}$ (III) can suppress $\mathrm{Hg}$ methylation by complexing $\mathrm{Hg}$ and making it unavailable for methylation (Si et al. 2015). Methanogens (Hamelin et al. 2011), IRB (Yu et al. 2012), and SRB (Compeau and Bartha 1985) are facultative anaerobes (Hintelmann 2010); however, anaerobic bacteria are not significant sources of MeHg to the ocean in oxygen-deficient zones (Malcolm et al. 2010), suggesting that aerobic bacteria may have a greater role than previously thought. The methylating activity of IRB, methanogens, and SRB may function as part of a large community of other closely interacting microorganisms. Several methanogens (e.g., Methanomethylovorans hollandica and Methanolobus tindarius) have been found to have methylating properties (Gilmour et al. 2013), and contrary to past research that asserted methanogens had only a minor role in methylation (Ullrich et al. 2001), methanogens may in fact be the primary methylators in particular environments such as fluvial lakes (Hamelin et al. 2011).

A developing area of research that is likely to enable significant strides in the future identification of methylating biota is the tracing of the gene pair $\operatorname{lgc} A B$, which is necessary for methylation (Gilmour et al. 2013; Parks et al. 2013). Known methylators, including SRB and IRB, possess the genes responsible for methylation (Gilmour et al. 2013; Parks et al. 2013; Sonke et al. 2013; Podar et al. 2015). This gene pair has already enabled researchers to identify the methylating capacities of certain methanogens as well as Firmicutes (Parks et al. 2013), particularly syntrophic, acetogenic, and fermentative varieties (Gilmour et al. 2013), several Proteobacteria, including five Deltaproteobacteria species (Gilmour et al. 2013), and Euryarchaeota of the archaea (Parks et al. 2013) (Table 2).

The presence of the $h g c$ gene cluster in organisms from environments that are methanogenic (such as rice paddies or animal digestive systems) or with conditions at the extremes of $\mathrm{pH}$ and salinity levels (Gilmour et al. 2013) could significantly broaden the range of environments at a high risk for $\mathrm{Hg}$ methylation, beyond those that feature sulfate or iron reduction as dominant processes. Potential environments in which methylation may occur, as suggested by the environments of organisms with the $h g c A B$ gene cluster, include invertebrate digestive tracts, thawing permafrost soils, coastal dead zones, and extreme environmental conditions (Podar et al. 2015). In fact, studies using molecular 
Table 2. Organisms that have been identified as either methylators or having the $h g c A B$ homologue.

$\begin{array}{llll}\text { Kingdom } & \text { Group } & \text { Genus and species } & \text { Additional info, reference }\end{array}$

Presence of $h g c A B$ homologue plus stable isotope incubations

\begin{tabular}{|c|c|c|c|}
\hline Archaea & Methanomicrobia & $\begin{array}{l}\text { Methanomethylovorans hollandica } \\
\text { Methanolobus tindarius }\end{array}$ & Gilmour et al. (2013) \\
\hline Bacteria & Firmicutes & $\begin{array}{l}\text { Ethanoligenens harbinense } \\
\text { Dethiobacter alkaliphilus } \\
\text { Desulfosporosinus acidiphilus } \\
\text { Desulfitobacterium metallireducens } \\
\text { Desulfosporosinus youngiae } \\
\text { Desulfitobacterium dehalogenans } \\
\text { Acetonema longum }\end{array}$ & Gilmour et al. (2013) \\
\hline Bacteria & Deltaproteobacteria & $\begin{array}{l}\text { Geobacter bemidjiensis } \\
\text { Desulfonatronospira thiodismutans } \\
\text { Desulfomicrobium baculatum } \\
\text { Geobacter daltonii } \\
\text { Syntrophus acidotrophicus }\end{array}$ & Lu et al. (2016); Gilmour et al. (2013) \\
\hline
\end{tabular}

Presence of $h g c A B$ homologue plus other tests

\begin{tabular}{|c|c|c|c|}
\hline Bacteria & Deltaproteobacteria & $\begin{array}{l}\text { Desulfovibrio aespoeensis } \\
\text { Desulfovibrio desulfuricans } \\
\text { Desulfovibrio africanus } \\
\text { Desulfobulbus propionicus }\end{array}$ & $\begin{array}{l}\text { Sulfate reducing bacteria inhibitors (Compeau and Bartha 1985; Kerry et al. 1991; } \\
\text { Gilmour et al. 1992; Choi and Bartha 1993; Choi et al. 1994) } \\
\text { Correlations with } \mathrm{SO}_{4} \text { concentrations (Devereux 1996; King et al. 1999; Eckley } \\
\text { and Hintelmann 2006) } \\
\text { Presence of hgc gene cluster (Gilmour et al. 2013; Parks et al. 2013; Sonke et al. } \\
\text { 2013; Podar et al. 2015) }\end{array}$ \\
\hline
\end{tabular}

Stable isotope assays only

$\begin{aligned} \text { Bacteria Deltaproteobacteria } & \text { Geobacter metallireducens } \\ & \text { Desulfuromonas palmitatis } \\ & \text { Geobacter hydrogenophilus } \\ & \text { Geobacter sulfurreducens }\end{aligned}$

\section{Correlations to increased $\mathrm{MeHg}$ concentrations}

\begin{tabular}{|c|c|c|c|}
\hline Bacteria & Deltaproteobacteria & Geobacter sp. & Fleming et al. (2006) and Yu et al. (2012) \\
\hline Bacteria & Deltaproteobacteria & $\begin{array}{l}\text { Desulfotomaculum ruminis } \\
\text { Desulfovibrio piger } \\
\text { Desulfovibrio giganteus } \\
\text { Desulfovibrio termitidis } \\
\text { Desulfobulbus propionicus }\end{array}$ & Kaschak et al. (2014) \\
\hline Bacteria & Deltaproteobacteria & Geobacter sulfurreducens & Si et al. (2015) and Yu et al. (2012) \\
\hline
\end{tabular}

\section{Radiochemical assays}

Bacteria Cyanobacteria Microcystis aeruginosa Assay using ${ }^{203} \mathrm{Hg}$ additions (Coelho-Souza et al. 2006)

Presence of $h g c A B$ homologue only

Bacteria Deltaproteobacteria Nitrospina sp. Gionfriddo et al. (2016)

techniques to directly examine potential sites of methylation are currently being published. For example, Gionfriddo et al. (2016) have identified Antarctic sea ice as a possible environment conducive to the growth of a marine microaerophilic bacterium (Nitrospina) by isolating the $h g c A B$ genes 
in environmental samples. Identifying and tracing the $h g c A B$ gene cluster will likely be crucial to significant future developments in mercury methylation research in determining both the range of environmental conditions that may support methylation, as well as individual methylating species.

\section{Where does methylation occur?}

\section{Wetlands and sediments}

Methylation of $\mathrm{Hg}$ occurs in the vast majority of aquatic systems, indicating a wide variety of possible environmental conditions, and by extension, a wide range of geographical locations. Methylation has been extensively studied in boreal lakes and wetlands (Beijer and Jernelov 1979; Regnell 1994; Matilainen and Verta 1995; Pak and Bartha 1998; Benoit et al. 2002; Eckley and Hintelmann 2006), notably at the Experimental Lakes Area in northwestern Ontario, where much of the early work surrounding factors influencing methylation was done (Furutani and Rudd 1980; Ramlal et al. 1986, 1993; Miskimmin et al. 1992; Kelly et al. 1997; St. Louis et al. 2004; Harris et al. 2007). The importance of wetlands as sites of methylation was first determined in boreal wetlands (Zillioux et al. 1993; St. Louis et al. 1994, 1996; Branfireun et al. 1998, 1999; Tjerngren et al. 2012b) and has been recently observed in wetlands in the northern Great Plains (Hoggarth et al. 2015), southern Louisiana (Hall et al. 2008), the high Arctic (Lehnherr et al. 2012), in agricultural and non-agricultural wetlands (MarvinDiPasquale et al. 2014), and temperate forests (Selvendrian et al. 2008). Methylation also occurs in a number of saline, estuarine, and marine environments (e.g., Olson and Cooper 1974; Compeau and Bartha 1985, 1987; Mason et al. 1993), and recently it has been observed in the surface sediments of mudflats (a type of coastal wetland) (Ouddane et al. 2008), mangroves (de Oliveira et al. 2015), and lagoons (Bloom et al. 2004; Coelho-Souza et al. 2006; Monperrus et al. 2007a; Faganeli et al. 2012; Guédron et al. 2012; Hines et al. 2012). The porewaters of peatland have also been found to be a primary source of $\mathrm{MeHg}$ to the surrounding environment (Mitchell et al. 2008a), demonstrating the importance of these minuscule interstitial spaces in larger environmental impacts. The sediments of aquatic environments are important sites of methylation, particularly at the interface with water.

Recent studies have confirmed the sediments and porewater of aquatic environments to be key locations of methylation and have elucidated how methylation potential may change in proportion to depth within the sediment. Higher \% MeHg in mudflats (Ouddane et al. 2008), higher MeHg concentrations in lagoons (Monperrus et al. 2007b), and higher potential methylation and demethylation rates in Gulf of Mexico sediments (Liu et al. 2015) were found in the surface sediment compared with deep sediment, confirming past research that suggested that methylation occurs primarily in the upper layers of sediment where there is significant microbial activity (Rudd et al. 1983; Korthals and Winfrey 1987; Matilainen 1995). A similar effect has been observed in peatland porewaters, with higher MeHg concentrations found nearer to the surface (Selvendrian et al. 2008). Decreases in methylation potential with increasing distance from the sediment-water interface may be due to bacteria from the sediment moving into the water column once oxygen is depleted (Eckley and Hintelmann 2006), which is further supported by the fact that sulfate reduction rates are positively correlated with methylation rates in terms of sediment depth (King et al. 1999; Merritt and Amirbahman 2009). This may be due to depth-dependent variations in the availability of electron donors (such as organic acids, long-chain fatty acids, hydrogen, aliphatic hydrocarbons, and simple aromatic compounds) that are required for bacterial methylation processes (Devereux 1996; Merritt and Amirbahman 2009). Branfireun et al. (1996) suggested that this effect may be due to greater labile carbon input and exposure, greater nutrient availability, anoxic conditions, abundant methylating microbes, and warmer temperatures nearer to the surface, which all support methylation. High methylation rates at the sediment-water interface with depth-correlated decreases may also be the result of either sulfur(II)-mediated inhibition of methylation or a diminution of the quality of organic substrates for the metabolic activity of SRB (Merritt and Amirbahman 2009). 


\section{Benthic surfaces}

Methylation has also been found to occur in periphyton (which is primarily composed not only of algae, but also fungi, bacteria, protozoa, and metazoa) (Cleckner et al. 1999; Žižek et al. 2011). Achá et al. (2011) examined periphyton associated with the roots of tropical macrophytes Eichhornia crassipes (common water hyacinth) and Polygonum densiflorum (knotweed), where anaerobic or microaerophilic bacteria are able to grow within the periphyton biofilm (EnrichPrast et al. 2004; Achá et al. 2011). Periphyton associated with the floating roots of macrophytes was found to be the primary location of methylation in tropical freshwater environments (Coelho-Souza et al. 2006). In tropical lakes, the phytoplankton responsible for methylation in the periphyton include Microcystis aeruginosa and Synechocystis species; however, it is unknown whether these phytoplankton are acting in association with other bacteria (Coelho-Souza et al. 2006), indicating a gap in the literature that warrants further exploration. In Canadian fluvial wetlands, Hamelin et al. (2015b) observed levels of net $\mathrm{MeHg}$ production in the periphyton that were two orders of magnitude greater than those in the sediment. Furthermore, there was a direct correlation between the methylation rate constant and the $\mathrm{MeHg}$ concentration of the periphyton; concentrations that were $10 \times$ higher than in the lake's macrophytes (Hamelin et al. $2015 a, 2015 b)$. It is evident that significant amounts of methylation occur not only in sediments but also in the periphyton of aquatic environments. Methylation in periphyton could have significant implications for biota, as periphyton can be an important source of food and nursing sites for fish.

\section{Pelagic environments}

While sediments are the primary location of methylation, methylation may also occur-albeit to a lesser extent-in the water column of aquatic systems (Olson and Cooper 1974; Korthals and Winfrey 1987; Xun et al. 1987; Ullrich et al. 2001). Recent work has shown that euphotic surface waters of the ocean are a potential location of methylation. Soerensen et al. (2016) found that the majority of net $\mathrm{MeHg}$ production occurred at a depth of between 20 and $200 \mathrm{~m}$ in the Arctic Ocean. Plankton abundances have been found to fluctuate in correlation with $\mathrm{MeHg}$ concentrations in ocean waters (Heimbürger et al. 2010; Kirk et al. 2012), and it has been hypothesized that methylation in oxic ocean waters (Monperrus et al. 2007a), lagoon water columns (Monperrus et al. 2007b), tropical lakes (Coelho-Souza et al. 2006), and hydroelectric reservoirs (Si et al. 2015) is affected by the abundance and activity of pelagic microorganisms like phytoplankton and bacterioplankton. Methylation in Arctic marine ecosystems (Pongratz and Heumann 1998, 1999; Lehnherr et al. 2011; Kirk et al. 2012) may be accomplished by macroalgae (Pongratz and Heumann 1998) or marine bacteria (Pongratz and Heumann 1999) in the water column (Lehnherr et al. 2011), open polynyas (St. Louis et al. 2007), or shelf sediments and rivers in coastal regions (Fitzgerald et al. 2007; Kirk et al. 2012).

Recent studies have focused on methylation in the water column of still bodies, where higher concentrations of $\mathrm{MeHg}$ and spikes in $\mathrm{MeHg}$ formation have been strongly associated with anoxic conditions (Eckley and Hintelmann 2006; Johnson et al. 2015). In several Canadian lakes, methylation in the water column was detected only in the lower, cooler, and stagnant anoxic hypolimnia, with the highest methylation potential measured just below the oxycline and decreasing with depth in the water column (Eckley and Hintelmann 2006). However, this contradicts studies of oxygen-deficient zones of marine systems, where anaerobic bacteria were not significant sources of $\mathrm{MeHg}$, which in turn aligns with other studies that demonstrated a positive correlation between $\mathrm{MeHg}$ concentration and decomposing organic matter in the oxic water column (Malcolm et al. 2010). Recent research suggests that the water column may prove to be a significant zone of methylation in certain aquatic environments. 


\section{Inundated environments}

Increases in $\mathrm{MeHg}$ concentrations in flooded environments result from the stimulation of microbial methylators by organic material supplied via decaying vegetation and soils (Bodaly et al. 1984; Kelly et al. 1997; Hall and St. Louis 2004; Hall et al. 2004, 2005), resulting in elevated fish Hg concentrations 10-20 years post impoundment (Bodaly et al. 2007). Revisiting the sites of inundated terrestrial areas nine years after initial flooding has shown that $\mathrm{MeHg}$ concentrations in the once flooded soils remain elevated (Rolfhus et al. 2015). Recent studies have focused on the influence of fluctuating inundation on methylation potential, particularly on the enhancement of methylation through the exposure of the sediment to atmospheric oxygen, which may promote sulfate recycling via sulfide oxidation, thus providing additional sulfate resources for SRB (Eckley et al. 2015). In a boreal peatland study, oxidation during droughts encouraged the mobilization of $\mathrm{MeHg}$ to peat porewaters when the land was re-flooded, allowing for increased $\mathrm{MeHg}$ production, particularly in the areas of peatland that had increased atmospheric sulfate deposition (Coleman Wasik et al. 2015). In addition, inundation and stagnation may reduce oxygen availability in the sediment as pores fill with water, thus encouraging the activity of anaerobic bacteria (Briggs et al. 2015; Singer et al. 2016). In this case, the frequency of inundation should be considered when determining the risks of mercury contamination in particular aquatic environments, as the frequency and duration of inundation have been found to be correlated with estimated MeHg production potential (Singer et al. 2016). Lower frequencies of inundation have been correlated to lower production potential (Singer et al. 2016), which may be linked to the potential of extended inundation to encourage $\mathrm{MeHg}$ degradation. Both flow frequency and inundated area have been found to determine production potential, rather than flood magnitude alone (Singer et al. 2016). Temporal flooding also results in an increased volume of sediment in which methylation can take place (Heim et al. 2007; Sizmur et al. 2013). Recent research suggests that prairie wetlands with temporal hydrological patterns of drying and re-flooding can promote methylation over permanently inundated environments, provided that the flooding periods are not sufficiently long to promote MeHg degradation (Sando et al. 2007).

The influence of flooding is also demonstrated through the disproportionately higher levels of $\mathrm{MeHg}$ found in rice compared with other crops, which is a result of its cultivation in flooded conditions that increases the anoxic environment in which methylating organisms thrive (Qiu et al. 2008). The majority of recent studies on methylation in rice paddies have examined contaminated systems (Rothenberg et al. 2014), which are beyond the scope of this paper. However, methylation has been found to occur in non-contaminated rice cultivation sites around the world including Brazil (da Silva et al. 2010; Batista et al. 2012; Silva et al. 2012), China (Rothenberg et al. 2011), and Spain (da Silva et al. 2013). The use of stable isotope tracers recently confirmed that MeHg produced in saturated soils is subsequently observed in the plant's rice grains (Strickman and Mitchell 2017), suggesting that the prevalence of methylation in rice paddies is a significant concern due to its potential to cause mercury poisoning directly through a common staple food source. However, Strickman and Mitchell (2017) also found significant MeHg losses between flowering and maturity; evidence of in planta demethylation that has also been observed in the roots rice exposed to more elevated $\mathrm{Hg}$ concentrations typical of contaminated rice paddies (Xu et al. 2016). Understanding the relationships of the plant life cycle and changes in mercury speciation could have implications for the management of rice production, for example, timing the flooding of fields to reduce the uptake of $\mathrm{MeHg}$ from soil before flowering to reduce the translocation of $\mathrm{MeHg}$ into grains (Peng et al. 2012). Exposing rice paddies to aerobic conditions reduced the uptake of $\mathrm{MeHg}$ by plants, perhaps due to a reduction in the amount of SRB in aerobic conditions and water management strategies that include exposing soil to the air during particular phases of growth may lessen the risks of methylation (Wang et al. 2014). However, it is unclear whether the effects of re-flooding, which seem to promote methylation in other environments, would negate the benefits of aerobic cultivation. While a complete picture of the effects 
of temporal flooding on methylation in rice paddies is unclear, its effects in other aquatic environments have been more intensively studied.

\section{What abiotic factors control mercury methylation?}

The factors controlling biotic methylation are those that influence the activity of methylating bacteria, affect Hg bioavailability, or both (Benoit et al. 1999, 2002; Heyes et al. 2006), and include the concentration of bioavailable $\mathrm{Hg}$, temperature, $\mathrm{pH}$, redox potential, and the presence of complexing agents (presented in more detail below) (Celo et al. 2006). It is in the study of these factors that the newer techniques of stable isotope and genomic methods have begun to clarify some of the confounding issues of multiple controls on $\mathrm{MeHg}$ production.

\section{Oxygen availability}

Anoxic environments have been established over decades of research as the primary location of methylation (Compeau and Bartha 1985; Watras et al. 1995b; Warner et al. 2003; Sonke et al. 2013) and contemporary research has continued to observe the importance of anoxic conditions to methylation potential due to the fact that most sediments are anoxic. However, there is growing evidence that methylation can occur in both reducing and oxic environments such as the oxic surface waters of the ocean (Monperrus et al. 2007a; Heimbürger et al. 2010; Sonke et al. 2013) and polar marine waters (Lehnherr et al. 2011; Sonke et al. 2013). Liu et al. (2015) found no relationship for MeHg concentrations and trends in water column hypoxia in the Gulf of Mexico, although potential rates of both methylation and demethylation were higher than in other coastal systems (Table 1). Methylation in macrophyte roots of tropical lakes was observed only in lakes with oxic conditions (Correia et al. 2012). Another study detected methylation in the proximity of marine snow, which are aggregates of exopolymers, planktonic and bacterial cells, and organic matter that form differently sized particles $300 \mu \mathrm{m}$ or greater (Ortiz et al. 2015). While the authors suggest that anoxic areas around these aggregations provide ideal conditions for methylation (Ortiz et al. 2015), others consider the marine snow itself an oxic environment in which methylation may be occurring (Sonke et al. 2013). Other research has demonstrated positive correlations with oxygenic conditions such as those that exist in photosynthetic blooms in marine waters and MeHg concentrations (Cossa et al. 2009; Sunderland et al. 2009; Heimbürger et al. 2010). Oxic conditions may even influence methylation in the sediment, as high methylation has been observed in the upper layers of sediment below oxygenated water (Korthals and Winfrey 1987; Eckley and Hintelmann 2006), in contrast to lower methylation in sediment below anoxic water (Watras et al. 1995b; Eckley and Hintelmann 2006). One possible explanation of the association of oxic conditions with methylation is that some methylating bacteria are not anaerobic, but in fact require oxygen (Eckley and Hintelmann 2006). Recent research suggests that methylation occurs not only in anoxic environments, as has been well established, but may occur in oxic conditions as well. The role of microbial organisms able to methylate in oxic environments will become clearer as the use of the gene pair to determine methylators and the metabolic requirements of these organisms expands.

\section{Organic matter}

It has been well-established that dissolved organic matter (DOM) stimulates microbial activity, and by extension, methylation (Furutani and Rudd 1980; Hall et al. 2004, 2005; Ravichandran 2004). Organic matter produced in wetlands complexes $\mathrm{MeHg}$ (Ravichandran 2004), thereby enabling its transport to surface waters, but it can also complex inorganic $\mathrm{Hg}$, thereby decreasing $\mathrm{Hg}$ bioavailability (Miskimmin et al. 1992; Driscoll et al. 1995; Watras et al. 1995a; Barkay et al. 1997; Ullrich et al. 2001; Eckley and Hintelmann 2006). A number of recent studies have confirmed significant correlations with organic matter and $\mathrm{MeHg}$ concentrations. In freshwater wetlands in the Adirondack Mountain region of New York, the highest concentrations of MeHg were observed during growing periods, which were also periods of high decomposition (Selvendrian et al. 2008). In subarctic and boreal lakes, DOM 
was the variable most strongly associated with $\mathrm{MeHg}$ concentration regardless of climate, deposition patterns, or system size (Braaten et al. 2014). Faganeli et al. (2012) found that organic matter in lagoons was important in stimulating microbial methylating activity and that rapid degradation of organic matter by microbial activity is a seasonally fluctuating environmental condition that affects $\mathrm{Hg}$ bioavailability. In Louisiana wetlands within a salinity gradient, Hall et al. (2008) observed that concentrations of $\mathrm{MeHg}$ were correlated with the fraction of highly reactive dissolved organic carbon (DOC). While concentrations of DOM in marine systems are lower than in freshwater systems, the availability of organic carbon has been correlated to $\mathrm{MeHg}$ distribution in marine surface and intermediate waters in the Arctic (Cossa et al. 2009; Sunderland et al. 2009; Kirk et al. 2012), north Pacific (Sunderland et al. 2009), and Mediterranean (Cossa et al. 2009), as well as in estuarine (Lambertsson and Nilsson 2006) and marine (Mazrui et al. 2016) sediment. In rice paddies, the organic matter from rice waste both acts a nutrient source for methylating microbes and promotes the partitioning of $\mathrm{MeHg}$ to the dissolved phase (Rothenberg et al. 2011), thereby potentially increasing its bioavailability (Fleck et al. 2014). In tundra lakes with varying levels of DOC due to slumping permafrost, $\mathrm{MeHg}$ uptake to aquatic invertebrates was stimulated as DOC concentrations increased, until $\sim 8.5 \mathrm{mg} \mathrm{C} \cdot \mathrm{L}^{-1}$, after which there was an inhibitory effect (French et al. 2014).

The influence of DOM on methylation is often confounded by sulfur geochemistry. In environments where sulfate is not limited, methylation is primarily determined by the availability of organic matter; however, in environments with a sulfide concentration of over $0.01 \mu \mathrm{M}$, mercury sulfide complexes form preferentially, making binding with DOC less significant in determining methylation (Benoit et al. 2001). An additional effect of DOM, particularly aromatic carbon, is its potential to enhance the release of $\mathrm{Hg}$ from insoluble cinnabar (Waples et al. 2005), which can serve as a source of mercury to the food web through methylation. Given that cinnabar is the most commonly occurring form of mercury (Boening 2000), this can pose a significant risk for elevated MeHg in aquatic organisms. Organic matter functions in multiple ways to promote and enhance $\mathrm{Hg}$ methylation through its capacity to stimulate microbial activity, provide methyl groups for methylation, and release $\mathrm{Hg}$ from cinnabar, potentially enabling its methylation.

\section{Sulfur}

The presence of sulfur has repeatedly been found to have strong correlations to $\mathrm{MeHg}$ levels in several types of aquatic environments. As the activity of SRB is controlled in part by the presence of sulfate, increased sulfate can stimulate methylation (Gilmour et al. 1992; King et al. 1999). Low sulfide concentrations allow for the formation of neutral mercury sulfide complexes capable of diffusing through cell membranes, thereby promoting methylation, whereas higher concentrations can result in charged mercury sulfide complexes that decrease Hg bioavailability (Benoit et al. 1999). The influence of sulfate was recently demonstrated in an experiment that manipulated atmospheric sulfate loading to a small boreal peatland, demonstrating that both $\mathrm{MeHg}$ concentrations and $\% \mathrm{MeHg}$ in porewaters increased within a week of sulfate addition and declined as sulfate disappeared (Jeremiason et al. 2006; Coleman Wasik et al. 2012). The stimulation of MeHg production decreased once the addition of sulfate was discontinued; however, even four years later, $\mathrm{MeHg}$ concentrations and $\% \mathrm{MeHg}$ were still higher than in control systems (Coleman Wasik et al. 2012). In a related mesocosm study, Mitchell et al. (2008b) found that while additions of labile organic carbon to peat did not stimulate methylation, sulfate, both alone and in combination with some forms of organic $\mathrm{C}$, increased methylation production significantly. They also found that $\mathrm{MeHg}$ concentrations in treatments receiving both sulfate and carbon additions were similar to those previously measured in $\mathrm{MeHg}$ "hot spots" found near the interface of upland and peatland systems.

It is worth noting that not all environments with high sulfate concentrations are MeHg production "hotspots". Prairie wetland sites with naturally high sulfate values (up to thousands of $\mathrm{mg} \cdot \mathrm{L}^{-1}$ ) well 
within the range of concentrations that have be found to be inhibitory to methylation (Gilmour et al. 1998; Benoit et al. 2001) had higher MeHg proportions in the sediment and higher MeHg concentrations in surface water, but not higher potential methylation rates (Hoggarth et al. 2015). High electrical conductivities (driven by high sulfate concentrations) may have resulted in low partitioning coefficients in the high sulfate sites suggesting that porewater sulfide accumulation may have been preferentially pulling $\mathrm{Hg}$ into the porewater phase. While there continue to be clear correlations between the presence of sulfate and methylation potential, and developing research suggests methylation is positively correlated with the presence of sulfides, $\mathrm{Hg}$ cycling and methylation in naturally high sulfate sites have not been adequately investigated and may be an area of future research.

\section{Temperature}

Previous research has suggested that warmer water temperatures may promote bacterial methylation (Bacci 1989; Bodaly et al. 1993; Ramlal et al. 1993), which is supported by recent studies that identified a positive correlation for $\mathrm{MeHg}$ production rates and temperature (Monperrus et al. 2007a; Johnson et al. 2016). In some cases, methylation could only be detected in lake hypolimnia (which are perpetually cold due to a lack of thermal circulation) (Eckley and Hintelmann 2006), but this also is likely due to the anoxic nature of hypolimnia; the link between methylation and cool temperatures is ultimately unclear. Lower $\mathrm{MeHg}$ concentrations and \% $\mathrm{MeHg}$ in subarctic lakes compared with boreal lakes were believed to be due to lower temperatures not suitable for methylation, but differing $\mathrm{Hg}$ deposition patterns between sites was also presented as an explanation (Braaten et al. 2014). The influence of temperature on methylation may, therefore, be dependent on the climatic conditions of the specific aquatic environment under study. In addition, confounding factors such as increased anoxia in hypolimnetic areas make it difficult to fully assess the impact of temperature on methylation in situ.

\section{Salinity, pH, and trophic status}

Previous research has found low-salinity environments to be linked to higher levels of net methylation (Blum and Bartha 1980; Compeau and Bartha 1987; Barkay et al. 1997); however, recent studies have shown salinity to both stimulate, and to have no correlation with, methylation potential (e.g., Braaten et al. 2014). In laboratory conditions at a constant $\mathrm{pH}$ of 5.3, $\mathrm{MeHg}$ concentrations were found to be highest at a salinity of $0.5 \mathrm{~mol} \cdot \mathrm{L}^{-1}$, and concentrations declined as salinity rose (Chen et al. 2015). No correlations were observed for salinity and $\mathrm{MeHg}$ concentrations in natural mangrove ecosystems (de Oliveira et al. 2015) or hypersaline lakes (Johnson et al. 2015). The effect of pH conditions on methylation is equally unclear. While prior research demonstrated that the highest levels of methylation were typically associated with acidic environments (Ramlal et al. 1986; Bloom et al. 1991; Gilmour and Henry 1991; Spry and Wiener 1991; Ullrich et al. 2001), recent studies have observed methylation to occur only in tropical lakes with a neutral $\mathrm{pH}$ (Correia et al. 2012) and in prairie wetlands with $\mathrm{pH}$ above 8 (Hoggarth et al. 2015). In sub-Arctic and boreal lakes the opposite was observed, in that both $\mathrm{MeHg}$ concentration and $\% \mathrm{MeHg}$ were positively correlated to $\mathrm{pH}$ and alkalinity (Pennanen et al. 1998; Braaten et al. 2014).

The trophic status of a lake may also be an important consideration. In oligotrophic systems, nitrogen availability was positively correlated with $\mathrm{MeHg}$ concentration and \% $\mathrm{MeHg}$, suggesting that in some systems methylation may be stimulated by N availability (Braaten et al. 2014). Eutrophic conditions are also believed to influence methylation (Todorova et al. 2009), though this may be due to the enhancement of methylation in the presence of organic matter. In an eutrophic and hypolimnetic reservoir in Idaho sediments that were rich in organic matter, low in dissolved oxygen, under redox conditions, and with increased nutrient content were suggested to lead to elevated methylation rates compared with other systems (Gray and Hines 2009). This is in contrast to other recent studies that have observed negative correlations of nitrate and $\mathrm{MeHg}$ concentrations in the water column of 
eutrophic lakes (Todorova et al. 2009). A mesocosm study of estuarine sediments that were amended with various levels of $\mathrm{N}$ and $\mathrm{P}$ loadings to surface water showed that increased nutrients led to increased phytoplankton biomass productivity with stimulated microbial activity in sediments with $\mathrm{Hg}$ tracers that were considered highly bioavailable. However, low bioavailability $\mathrm{Hg}$ tracers showed no response, suggesting both increased sediment productivity and bioavailability-controlled $\mathrm{MeHg}$ production (Liem-Nguyen et al. 2016). The influence of salinity, pH, and eutrophic conditions on methylation remains unclear and may only form part of a set of interconnected environmental variables that determine methylation.

\section{Iron and manganese oxides}

Iron and manganese oxides have been found to significantly influence $\mathrm{Hg}$ cycling and methylation. In sewage treatment plants that use hydrated ferric oxide for water purification, the highest levels of methylation were found in areas rich in dissolved $\mathrm{Fe}^{2+}$ and organic matter (Bravo et al. 2015). The presence of compounds containing hydroxyl radicals has been found to enhance methylation at low concentrations due to their ability to function as methyl donors during photomethylation, but these compounds degrade MeHg when present in excess (Chen et al. 2015). A study of a variety of lagoon systems found that regardless of $\mathrm{Hg}$ source, $\mathrm{Hg}$ was influenced by the transformations of other elements, particularly redox-sensitive and microbially important elements like sulfur, iron, and manganese, and by the interactions of those elements with organic material (Faganeli et al. 2012). The correlation of methylation and the presence of particular elements and compounds in a number of aquatic environments may be linked to the importance of those elements in the mediation of microbial activity, which in turn determines methylation potential.

\section{Light}

Light plays a role in regulating the opposing processes of methylation and demethylation (Sellers et al. 1996; Monperrus et al. 2007a). In conditions such as those in the euphotic zones of coastal and marine waters, light can stimulate phototrophic organisms to reduce $\mathrm{HgII}$ to $\mathrm{Hg} 0$, thus reducing the pool of inorganic $\mathrm{Hg}$ available to methylation organisms and exerting a crucial role in regulating levels of $\mathrm{MeHg}$ in surface waters (Grégoire and Poulain 2014). However, light also stimulates photosynthetic activity, which in turn influences the release of labile DOM that encourages methylating microbial activity. Monperrus et al. (2007a) found that peak methylation corresponded to seasonal conditions later in the summer, which were conducive to higher planktonic content suggesting that methylation was primarily mediated by heterotrophic activity. Recently, both $\mathrm{MeHg}$ concentration and $\% \mathrm{MeHg}$ were found to be negatively correlated with both lake size and catchment area (Braaten et al. 2014). As photodemethylation is considered the most important sink of $\mathrm{MeHg}$ in freshwater lakes (Lehnherr and St. Louis 2009), this negative correlation is likely due to the larger area of surface water in the catchment exposed to UV light degradation compared with smaller lakes, thereby decreasing the net amount of $\mathrm{MeHg}$ produced in situ or that has leached from catchment soils and wetlands (Lehnherr and St. Louis 2009; Braaten et al. 2014). As a result, organisms in larger lakes with greater catchment areas may be less subject to the deleterious effects of methylated $\mathrm{Hg}$, as photodemethylation processes may actively be breaking down this highly bioavailable $\mathrm{Hg}$ species. However, catchment wetlands are believed to be the primary location of methylation (St. Louis et al. 1994; Tjerngren et al. 2012a; Braaten et al. 2014), suggesting that such effects may be mitigated if the catchment wetland area is sufficiently large.

\section{Bioavailability of $\mathrm{Hg}$}

Production of $\mathrm{MeHg}$ requires inorganic $\mathrm{Hg}$ to be available to methylating organisms. Deposition of inorganic $\mathrm{Hg}$, although decreasing globally, is not expected to decline to zero. In addition, legacy $\mathrm{Hg}$ deposits currently sequestered in sediments, wetland soils, permafrost, and forests may become 
mobile under a number of scenarios such as forest fires, and the disturbance of soils, sediment, and permafrost, thus increasing the inorganic $\mathrm{Hg}$ available for $\mathrm{MeHg}$ production. However, the uptake of this critical substrate has been found to be limiting in the methylation process, especially in the absences of certain complexing thiols (Schaefer et al. 2011). Hsu-Kim et al. (2013b) provide an excellent review of the factors controlling bioavailable $\mathrm{Hg}$ and summarize four main hypotheses for the uptake through both outer and inner membranes. Inorganic $\mathrm{Hg}$ is generally complexed with chloride, sulfide, or DOM and can be taken up either by diffusion or active transport by transmembrane proteins (Hsu-Kim et al. 2013a). As well as dissolved forms, nanoparticles, collides, and crystalline particles may also be bioavailable (Aiken et al. 2011). Because of the complexity of the interactions among the various possible sources of bioavailable $\mathrm{Hg}$, chemical equilibrium modelling contains high degrees of uncertainty and therefore does not confidently predict bioavailability and perhaps a kinetics-based approach would be more illuminating (Hsu-Kim et al. 2013b). Regardless, experiments examining the impact of different environmental parameters on $\mathrm{MeHg}$ production in complex microbial communities simultaneously will hopefully allow for the development of models more descriptive of methylation.

The use of a genetically engineered bacterium that exhibits bioluminescence in response to the uptake of $\mathrm{Hg}$ into the cell (Selifonova et al. 1993) has provided some information on the influence of $\mathrm{Hg}$ speciation on bioavailability. This "bioreporter" has been successful in showing enhanced uptake of inorganic mercury when newly deposited (Chiasson-Gould et al. 2014), under low base cation concentrations (Daguené et al. 2012), and at lower pH (Kelly et al. 2003). The same bioreporter has been used to assess the bioavailability of $\mathrm{MeHg}$, showing that increasing chloride concentration resulted in increased $\mathrm{MeHg}$ uptake; the presence of both humic acids and cysteine reduced $\mathrm{MeHg}$ bioavailability (Ndu et al. 2012). This approach has also been used to show that dissolved organic carbon both mobilizes inorganic $\mathrm{Hg}$ and alters cell walls to facilitate uptake (Chiasson-Gould et al. 2014). The use of this technique, however, has challenges. For one, the bioreporter must be constructed, which can be time consuming. For example, it took Ndu et al. (2012) 20 cycles before the lux reporter proteins were synthesized by the bacterium of interest. In addition, significant care must be taken to ensure that the growth medium is not contaminated with low levels of $\mathrm{Hg}$ that will promote light production. Finally, the bacterium is generally not representative of methylating organisms, with experiments generally performed using Escherichia coli or Vibrio anguillarum, both Gram-negative bacteria capable of aerobic metabolism.

\section{How do we deal with so many confounding factors?}

It is clear that the vast majority of studies of the environmental factors exerted by DOM on methylation have been correlative rather than direct observations. However, molecular techniques have allowed research to explore the direct impact of environmental factors on the activity of methylating organisms. For example, using the model Hg-methylating bacterium Desulfovibrio desulfuricans ND132, Graham et al. (2013) examined Hg bioavailability in cell assays at gradients of DOM ( 1-8 $\left.\mathrm{ng} \cdot \mathrm{Hg} \cdot \mathrm{mg}^{-1} \mathrm{C}\right)$ and sulfide concentrations $(1-1000 \mu \mathrm{M})$. Methylation was significantly greater in DOM-amended assays (especially those with highly aromatic DOM isolates) as compared with control absent of DOM. In addition, they found that assays amended with high sulfur content were particularly effective at enhancing methylation. In another example of the use of molecular techniques it was observed that the greater relative abundance of organisms with known methylator gene sequences in the sediment microbiome of high carbon DOM, as opposed to oligotrophic, mesocosms (Graham et al. in review). Goñi-Urriza et al. (2015) showed that $h g c A B$ gene expression varied in Desulfovibrio dechloroacetivorans BerOcl when grown under sulidogenic conditions and different carbon sources. However, they were unable to relate gene expression to potential methylation rates. Although in its infancy, with the advent of new molecular techniques, including the recent development of clade-specific quantitative molecular probes (Christensen et al. 2016), future studies should 
be able to test the impact of differences in amounts and types of DOM directly on methylating organisms.

Until recently, research has focused on one or two environmental factors as a means of understanding the controls of $\mathrm{MeHg}$ production. Recent developments of the use of stable isotope tracers and geonomic work have begun to examine the synergies of multiple factors. For example, Keucharzyk et al. (2015) found that methylation rates in marine sediments were highest when mixed cell cultures were amended with carbon, regardless of whether inorganic $\mathrm{Hg}$ was added as dissolved nitrate salt or as nanoparticles of HgS (as also observed by Graham et al. (2013); see above). Similarly, nutrient loading that stimulated microbial activity indirectly by increasing phytoplankton biomass was as important as bioavailability of $\mathrm{Hg}$ available to methylators (Liem-Nguyen et al. 2016). The conclusion was that $\mathrm{MeHg}$ production is limited by microbial productivity, regardless of $\mathrm{Hg}$ bioavailability, and that there is a threshold over which $\mathrm{Hg}$ speciation becomes a contributing control on methylation.

\section{How will Hg methylation be impacted by a changing climate?}

As the chemistry of the earth's atmosphere continues to change with anthropogenic emissions of greenhouse gases, global circulation models predict substantial atmospheric warming of $2-4.5^{\circ} \mathrm{C}$ (Intergovernmental Panel on Climate Change (IPCC) 2014). The most significant impact predicted to accompany increased radiative forcing is the increased warming of the earth's surface, which is predicted to be greatest at the poles. As a result of this increased warming, a number of indirect impacts are predicted such as increased sea level rises and intensified hydrological cycles, which are anticipated to increase the frequency of both drought and deluge, both of which have ecological impacts of their own. Many of these impacts have the potential to change rates of net Hg production (Fig. 1), and our current and future understanding of the factors that control the $\mathrm{Hg}$ biogeochemical cycle will allow us to make better informed predictions on what these changes may be.

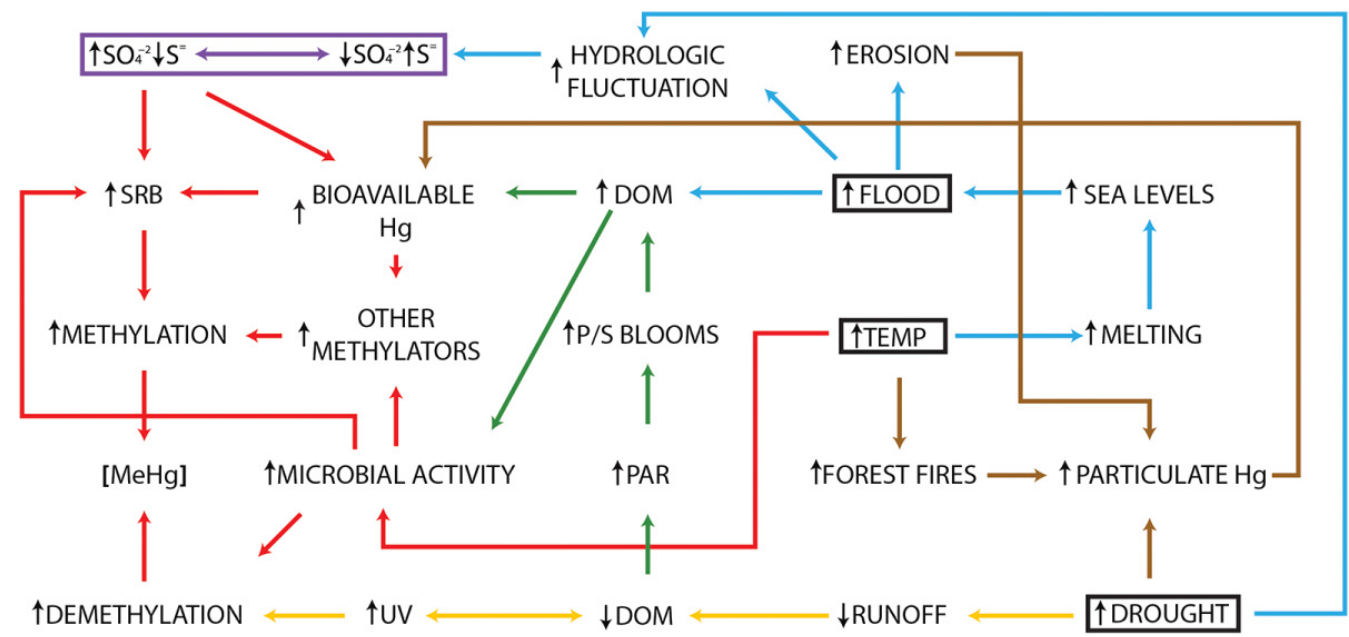

Fig. 1. A summary of the probable impacts of climate change on the changes in rates of methylation and demethylation resulting in changes in methylmercury concentrations ([MeHg]). Arrows up and down represent, respectively, positive and negative responses for variables including (but not limited to): temperature (TEMP), dissolved organic matter (DOM), sulfate and sulfide concentrations $\left(\mathrm{SO}_{4}{ }^{-2} \mathrm{~S}^{=}\right)$, photosynthetic blooms (P/S blooms), and the activity of sulfate-reducing bacteria (SRB). 


\section{Increased temperature}

Reviews of the impact of climate change on the Arctic have been published (Douglas et al. 2012; Stern et al. 2012); however, we touch briefly on a few here. Because the impacts of climate change are already being experienced in the Arctic, there has been recent work examining changes in $\mathrm{Hg}$ biogeochemistry with increased temperature. There have been a number of studies examining the impact of warming-induced ecosystem change from forested peat permafrost to treeless and permafrost-free thermokarst wetlands that is accompanied not only by increases of labile organic carbon (Jansson and Tas 2014; Yang et al. 2016b) but also by the release of inorganic Hg sequestered over decades of Hg deposition (Gordon et al. 2016). These changes, together with increased microbial activity as a result of warmer temperatures, have been hypothesized to result in greater rates of methylation and MeHg bioaccumulation in the Arctic (Podar et al. 2015; Yang et al. 2016a). Melting ice and permafrost may also increase river discharge to estuarine systems, with accompanying greater loads of bioavailable $\mathrm{Hg}$ and DOM, as well as increases in riparian area flooded, both factors in stimulating $\mathrm{Hg}$ methylation. However, increased temperature may also result in greater rates of microbial demethylation. Increased temperature will also result in the loss of sea ice and larger areas of open ocean susceptible to increased rates of photochemically mediated reactions in the $\mathrm{Hg}$ biogeochemical cycles (Stern et al. 2012). Interestingly, Girard et al. (2016) found that the rates of photodemethylation were higher in high DOC thaw ponds than in oligotrophic lakes, suggesting that some level of DOC is necessary for photodegradation to occur. Finally, increased temperatures will likely result in increased forest fires, which are a source of atmospheric deposited Hg sequestered in plants and soils (Kelly et al. 2006).

\section{Increased periods of deluge and drought}

Fluctuations in the hydrologic cycles will result in periods of deluge and drought. In the former, flooding of terrestrial matter will mimic reservoir creation and result in higher rates of methylation as well as an increase in the release of previously sequestered $\mathrm{Hg}$ in eroded soils. While increased drought may have a substantial impact on the release of sequestered $\mathrm{Hg}$ in dried soils that may be transferred from sources to lakes and wetlands, the most significant impact of drought on $\mathrm{Hg}$ cycling will be in those methylating systems (for a comprehensive examination of the impact of climate change on lakes and wetlands, see Schindler 1997). For example, decreases in hydrologic inputs to lakes and wetlands result in decreases in DOM and Hg inputs. Dissolved organic carbon is natural "sunscreen" for lakes, and declines would result in higher rates of photodemethylation in these systems. Higher rates of photodemethylation could counter higher rates of methylation that may result from increased temperatures or concentrations of microbial substrates such as DOM. Increases in lake residence time with decreased water inputs may result in increased productivity, also stimulating methylation; however, this may be countered by decreased inputs of DOM and Hg. Finally, the interplay between periods of drought and deluge will result in hydrological fluctuation, influencing the oxidation of sulfur species and thus impacting the activity of SRB. While the inherent complexity of ecological systems and the interacting factors within them necessarily complicate exact prediction of the effects of climate change on $\mathrm{Hg}$ methylation, increased temperature and subsequently enhanced patterns of deluge and drought are likely to promote $\mathrm{Hg}$ methylation beyond levels of any potential mitigating effects.

\section{Conclusion}

While research in mercury methylation over the past 10 years has largely confirmed the past understanding of $\mathrm{Hg}$ cycling, there have been a number of advances, perhaps most significantly the identification of the $h g c A B$ gene cluster, which is necessary for methylation, in many diverse organisms. This vastly broadens the scope of knowledge about methylating organisms and the environments in 
which they may reside. It also contradicts prior research asserting that SRB are the primary biotic methylators, because many microorganisms, including IRB, methanogens, and archaea, have been found to contain this gene pair. Recent studies have found that organisms containing this cluster may live in extreme environmental conditions, which illuminates the potential for a much broader environmental scope of methylating organisms. This innovation has the potential to develop not only our understanding of which organisms are capable of methylation, but also of the diversity of abiotic environmental conditions that may support methylation. It is, however, important to note that the mere presence of methylating capacities in organisms does not indicate that methylation will necessarily occur. Therefore, further study that not only identifies organisms with the capacity to methylate, but also examines the role of these organisms in situ, is required.

Recent research has identified the presence of methylation in numerous environments, including freshwater and brackish wetlands, which are thought to be more prominent in terms of methylation than marine wetlands and marine lakes, and estuarine systems and open marine waters, which have been identified as potential areas of methylation. The presence of $\mathrm{MeHg}$ in the open ocean may be due to methylation in the water column or may originate from the sediments of coastal regions. Research into the methylation potential of the open ocean requires further development, particularly in the polar regions, which is an ongoing concern due to increased atmospheric $\mathrm{Hg}$ deposition in the region. Inundated aquatic systems may also act as sources of $\mathrm{MeHg}$ to the surrounding environment, and include hydroelectric reservoirs, rice paddies, and more recently identified sewage treatment plants due to the stimulation of methylation by the use of ferric oxide. The examination of inundated anthropogenic systems adds another dimension to the conversation about methylation in aquatic systems, considering not only how anthropogenic $\mathrm{Hg}$ pollution can be biologically mobilized, but also how man-made environments may contribute to $\mathrm{MeHg}$ contamination via changes in net methylation.

Recent research has developed the notion that methylation may occur in oxic environments, both in pelagic environments and in the sediment exposed to oxygenated water or temporary droughts that expose sediments to air, both of which have been found to enhance methylation. There is mounting evidence that systems that experience temporal hydrological patterns may be loci of greater $\mathrm{MeHg}$ production. With the use of stable isotope tracers and the ability to measure potential methylation and demethylation rates, the understanding of environmental factors as controls on MeHg production is mainly in the form of correlations among rates and physiochemical factors. Synergies, both positive and negative, among environmental controls are just recently being examined, in part due to the use of molecular techniques made possible by the hgcAB discovery. In the future, a better understanding is required of the rates of demethylation, which, in some environs, may be very important in determining net $\mathrm{MeHg}$.

Finally, the incredibly complex responses of the earth's ecosystems to a changing climate will result in a myriad of possible changes to factors that control methylation and demethylation. Increased understanding of the mercury biogeochemical cycle will allow us better predictive abilities to assess responses in $\mathrm{Hg}$ cycling due to a changing climate. Recent molecular technology will likely guide the most significant strides in future research and enable a broadened understanding of the organisms that possess methylating capacities, the environments that these organisms can inhabit, and by extension, which environments may be at risk of $\mathrm{MeHg}$ contamination.

\section{Acknowledgements}

All funding for this work was provided by the University of Regina. The authors thank Geremy Lague for the graphic design of Fig. 1. 


\section{Author contributions}

Conceived and designed the study: ARP, BDH. Performed the experiments/collected the data: ARP. Analyzed and interpreted the data: ARP, BDH. Contributed resources: BDH. Drafted or revised the manuscript: ARP, BDH.

\section{Competing interests}

The authors have declared that no competing interests exist.

\section{Data accessibility statement}

All relevant data are within the paper.

\section{References}

Achá D, Hintelmann H, and Yee J. 2011. Importance of sulfate reducing bacteria in mercury methylation and demethylation in periphyton from Bolivian Amazon region. Chemosphere, 82: 911-916. doi:10.1016/j.chemosphere.2010.10.050.

Aiken GR, Hsu-Kim H, and Ryan JN. 2011. Influence of dissolved organic matter on the environmental fate of metals, nanoparticles, and colloids. Environmental Science \& Technology, 45: 3196-3201. PMID:21405118. doi:10.1021/es103992s.

Akagi H, Fujita Y, and Tkabatake E. 1974. Photochemical methylation of inorganic mercuric compounds in aqueous acetic acid solutions. Nippon Kagaku Kaishi, 7: 1180-1184. doi:10.1246/ nikkashi.1974.1180.

Avramescu M-L, Yumvihoze E, Hintelmann H, Ridal J, Fortin D, and Lean DRS. 2011. Biogeochemical factors influencing net mercury methylation in contaminated freshwater sediments from the St. Lawrence River in Cornwall, Ontario, Canada. Science of the Total Environment, 409: 968-978. PMID:21176945. doi:10.1016/j.scitotenv.2010.11.016.

Bacci E. 1989. Mercury in the Mediterranean. Marine Pollution Bulletin, 20: 59-63. doi:10.1016/ 0025-326X(89)90227-0.

Bailey LT, Mitchell CPJ, Engstrom DR, Berndt ME, Coleman Wasik JK, and Johnson NW. In press. The influence of porewater sulfide on methylmercury production and partitioning in sulfateimpacted lake sediments. Science of the Total Environment.

Barkay T, Gillman M, and Turner RR. 1997. Effects of dissolved organic carbon and salinity on bioavailability of mercury. Applied and Environmental Microbiology, 63: 4267-4271. PMID:9361413.

Batista BL, Nacano LR, de Freitas R, de Oliveira-Souza VC, and Barbosa F. 2012. Determination of essential (Ca, Fe, I, K, Mo) and toxic elements $(\mathrm{Hg}, \mathrm{Pb})$ in Brazilian rice grains and estimation of reference daily intake. Food and Nutrition Sciences, 3: 129-134. doi:10.4236/fns.2012.31019.

Beijer K, and Jernelov A. 1979. Methylation of mercury in aquatic environments. In The biogeochemistry of mercury in the environment. Edited by JO Nriago. Elsevier/North-Holland Biomedical Press, Amsterdam, The Netherlands. pp. 203-210.

Benoit JM, Gilmour CC, Mason RP, and Heyes A. 1999. Sulfide controls on mercury speciation and bioavailability to methylating bacteria in sediment pore waters. Environmental Science \& Technology, 33: 951-957. doi:10.1021/es9808200. 
Benoit JM, Mason RP, Gilmour CC, and Aiken GR. 2001. Constants for mercury binding by dissolved organic matter isolates from the Florida Everglades. Geochimica et Cosmochimica Acta, 65: 4445-4451. doi:10.1016/S0016-7037(01)00742-6.

Benoit JM, Gilmour CC, Heyes A, Mason RP, and Miller CL. 2002. Geochemical and biological controls over methylmercury production and degradation in aquatic ecosystems. In Biogeochemistry of environmentally important trace elements. Edited by Y Cai and OC Braids. American Chemical Society, Washington, D.C. pp. 262-297.

Bittrich DR, Rutter AP, Hall BD, and Schauer JJ. 2011. Photodecomposition of methylmercury in atmospheric waters. Aerosol and Air Quality Research, 11: 290-299. doi:10.4209/aaqr.2010.11.0096.

Bloom NS, Watras CJ, and Hurley JP. 1991. Impact of acidification on the methylmercury cycle of remote seepage lakes. Water, Air, and Soil Pollution, 56: 477-491. doi:10.1007/BF00342293.

Bloom NS, Moretto LM, Scopece P, and Ugo P. 2004. Seasonal cycling of mercury and monomethyl mercury in the Venice Lagoon (Italy). Marine Chemistry, 91: 85-99. doi:10.1016/j. marchem.2004.06.002.

Blum JE, and Bartha R. 1980. Effect of salinity on methylation of mercury. Bulletin of Environmental Contamination and Toxicology, 25: 404-408. PMID:7426790. doi:10.1007/BF01985546.

Bodaly RA, Hecky RE, and Fudge RJP. 1984. Increases in fish mercury levels in lakes flooded by the Churchill River Diversion, northern Manitoba. Canadian Journal of Fisheries and Aquatic Sciences, 41: 682-691. doi:10.1139/f84-079.

Bodaly RA, Rudd JWM, Fudge RJP, and Kelly CA. 1993. Mercury concentrations in fish related to size of remote Canadian Shield lakes. Canadian Journal of Fisheries and Aquatic Sciences, 50: 980-987. doi:10.1139/f93-113.

Bodaly RA, Jansen WA, Majewski AR, Fudge RJP, Strange NE, Derksen AJ, et al. 2007. Post-impoundment time course of increased mercury concentrations in fish in hydroelectric reservoirs of northern Manitoba, Canada. Archives of Environmental Contamination and Toxicology, 53: 379-389. PMID:17728990. doi:10.1007/s00244-006-0113-4.

Boening DW. 2000. Ecological effects, transport, and fate of mercury: a general review. Chemosphere, 40: 1335-1351. PMID:10789973. doi:10.1016/S0045-6535(99)00283-0.

Braaten HFV, de Wit HA, Fjeld E, Rognerud S, Lydersen E, and Larssen T. 2014. Environmental factors influencing mercury speciation in Subarctic and Boreal lakes. Science of the Total Environment, 476-477: 336-345. doi:10.1016/j.scitotenv.2014.01.030.

Branfireun BA, Heyes A, and Roulet NT. 1996. The hydrology and methylmercury dynamics of a Precambrian Shield headwater peatland. Water Resources Research, 32: 1785-1794. doi:10.1029/ 96WR00790.

Branfireun BA, Hilbert D, and Roulet NT. 1998. Sinks and sources of methylmercury in a boreal catchment. Biogeochemistry, 41: 277-291. doi:10.1023/A:1005964603828.

Branfireun BA, Roulet NT, Kelly CA, and Rudd JWM. 1999. In situ sulphate stimulation of mercury methylation in a boreal peatland: toward a link between acid rain and methylmercury contamination in remote environments. Global Biogeochemical Cycles, 13: 743-750. doi:10.1029/ 1999GB900033. 
Braune BM, Chételat J, Amyot M, Brown T, Clayden MG, Evans MS, et al. 2015. Mercury in the marine environment of the Canadian Arctic: review of recent findings. Science of the Total Environment, 509-510: 67-90. doi:10.1016/j.scitotenv.2014.05.133.

Bravo AG, Bouchet S, Guédron S, Amouroux D, Dominik J, and Zopfi J. 2015. High methylmercury production under ferruginous conditions in sediments impacted by sewage treatment plant discharges. Water Research, 80: 245-255. PMID:26005785. doi:10.1016/j. watres.2015.04.039.

Briggs MA, Day-Lewis FD, Zarnetske JP, and Harvey JW. 2015. A physical explanation for the development of redox microzones in hyporheic flow. Geophysical Research Letters, 42: 4402-4410. doi:10.1002/2015GL064200.

Bussan DD, Sessums RF, and Cizdziel JV. 2016. Activated carbon and biochar reduce mercury methylation in aquatic sediments. Bulletin of Environmental Contamination and Toxicology, 96: 536-539. PMID:26779648. doi:10.1007/s00128-016-1734-6.

Celo V, Lean DRS, and Scott SL. 2006. Abiotic methylation of mercury in the aquatic environment. Science of the Total Environment, 368: 126-137. PMID:16226793. doi:10.1016/j.scitotenv.2005.09.043.

Chen B, Chen P, He B, Yin Y, Fang L, Wang XW, et al. 2015. Identification of mercury methylation product by tert-butyl compounds in aqueous solution under light irradiation. Marine Pollution Bulletin, 98: 40-46. PMID:26165936. doi:10.1016/j.marpolbul.2015.07.015.

Chiasson-Gould SA, Blais JM, and Poulain AJ. 2014. Dissolved organic matter kinetically controls mercury bioavailability to bacteria. Environmental Science \& Technology, 48: 3153-3161. PMID:24524696. doi:10.1021/es4038484.

Choi S-C, and Bartha R. 1993. Cobalamin-mediated mercury methylation by Desulfovibrio desulfuricans LS. Applied and Environmental Microbiology, 59: 290-295. PMID:8439155.

Choi S-C, Chase T Jr, and Bartha R. 1994. Enzymatic catalysis of mercury methylation by Desulfovibrio desulfuricans LS. Applied and Environmental Microbiology, 60: 1342-1346. PMID:8017921.

Christensen GA, Wymore AM, King AJ, Podar M, Hurt RA Jr, Santillan EU, et al. 2016. Development and validation of broad-range qualitative and clade-specific quantitative molecular probes for assessing mercury methylation in the environment. Applied and Environmental Microbiology, 82: 6068-6078. PMID:27422835. doi:10.1128/AEM.01271-16.

Cleckner LB, Gilmour CC, Hurley JP, and Krabbenhoft DP. 1999. Mercury methylation in periphyton of the Florida Everglades. Limnology and Oceanography, 44: 1815-1825. doi:10.4319/ lo.1999.44.7.1815.

Coelho-Souza SA, Guimarães JRD, Mauro JBN, Miranda MR, and Azevedo SMFO. 2006. Mercury methylation and bacterial activity associated to tropical phytoplankton. Science of the Total Environment, 364: 188-199. PMID:16169057. doi:10.1016/j.scitotenv.2005.07.010.

Coleman Wasik JK, Mitchell CPJ, Engstrom DR, Swain EB, Monson BA, Balogh SJ, et al. 2012. Methylmercury declines in a boreal peatland when experimental sulfate deposition decreases. Environmental Science \& Technology, 46: 6663-6671. PMID:22578022. doi:10.1021/ es300865f. 
Coleman Wasik JK, Engstrom DR, Mitchell CPJ, Swain EB, Monson BA, Balogh SJ, et al. 2015. The effects of hydrologic fluctuation and sulfate regeneration on mercury cycling in an experimental peatland. Journal of Geochemical Research: Biogeosciences, 120(9): 1697-1715. doi:10.1002/ 2015JG002993.

Compeau GC, and Bartha R. 1985. Sulfate-reducing bacteria: principal methylators of mercury in anoxic estuarine sediment. Applied and Environmental Microbiology, 50: 498-502. PMID:16346866.

Compeau GC, and Bartha R. 1987. Effect of salinity on mercury-methylation activity of sulfate-reducing bacteria in estuarine sediments. Applied and Environmental Microbiology, 53: 261-265. PMID:16347274.

Correia RRS, Miranda MR, and Guimarães JRD. 2012. Mercury methylation and the microbial consortium in periphyton of tropical macrophytes: effect of different inhibitors. Environmental Research, 112: 86-91. doi:10.1016/j.envres.2011.11.002.

Cossa D, Averty B, and Pirrone N. 2009. The origin of methylmercury in open Mediterranean waters. Limnology and Oceanography, 54: 837-844. doi:10.4319/1o.2009.54.3.0837.

da Silva DG, Portugal LA, Serra AM, Ferreira SLC, and Cerdà V. 2013. Determination of mercury in rice by MSFIA and cold vapour atomic fluorescence spectrometry. Food Chemistry, 137: 159-163. PMID:23200004. doi:10.1016/j.foodchem.2012.10.019.

da Silva MJ, Paim APS, Pimentel MF, Cervera ML, and de la Guardia M. 2010. Determination of mercury in rice by cold vapor atomic fluorescence spectrometry after microwave-assisted digestion. Analytica Chimica Acta, 667: 43-48. PMID:20441864. doi:10.1016/j.aca.2010.04.016.

Daguené V, McFall E, Yumvihoze E, Xiang S, Amyot M, and Poulain AJ. 2012. Divalent base cations hamper $\mathrm{Hg}^{\mathrm{II}}$ uptake. Environmental Science \& Technology, 46: 6645-6653. doi:10.1021/es300760e.

de Oliveira DCM, Correia RRS, Marinho CC, and Guimarães JRD. 2015. Mercury methylation in sediments of a Brazilian mangrove under different vegetation covers and salinities. Chemosphere, 127: 214-221. PMID:25732633. doi:10.1016/j.chemosphere.2015.02.009.

Devereux R. 1996. Depth profile of sulfate-reducing bacterial ribosomal RNA and mercury methylation in an estuarine sediment. FEMS Microbiology Ecology, 20: 23-31. doi:10.1111/j.1574-6941.1996. tb00301.x.

Douglas TA, Loseto LL, Macdonald RW, Outridge PM, Dommergue A, Poulain A, et al. 2012. The fate of mercury in Arctic terrestrial and aquatic ecosystems, a review. Environmental Chemistry, 9: 321-355. doi:10.1071/EN11140.

Driscoll CT, Blette V, Yan C, Schofield CL, Munson R, and Holsapple J. 1995. The role of dissolved organic carbon in the chemistry and bioavailability of mercury in remote Adirondack lakes. Water, Air, and Soil Pollution, 80: 499-508. doi:10.1007/BF01189700.

Driscoll CT, Han Y-J, Chen CY, and Evers DC. 2007. Mercury contamination in forest and freshwater ecosystems in the northeastern United States. BioScience, 57: 17-28. doi:10.1641/B570106.

Drott A, Lambertsson L, Björn E, and Skyllberg U. 2008. Do potential methylation rates reflect accumulated methyl mercury in contaminated sediments? Environmental Science \& Technology, 42: 153-158. PMID:18350890. doi:10.1021/es0715851. 
Duran R, Ranchou-Peyruse M, Menuet V, Monperrus M, Bareille G, Goñi MS, et al. 2008. Mercury methylation by a microbial community from sediments of the Adour Estuary (Bay of Biscay, France). Environmental Pollution, 156: 951-958. PMID:18508166. doi:10.1016/j.envpol.2008.05.007.

Eckley CS, and Hintelmann H. 2006. Determination of mercury methylation potentials in the water column of lakes across Canada. Science of the Total Environment, 368: 111-125. PMID:16216310. doi:10.1016/j.scitotenv.2005.09.042.

Eckley CS, Luxton TP, McKernan JL, Goetz J, and Goulet J. 2015. Influence of reservoir water level fluctuations on sediment methylmercury concentrations downstream of the historical Black Butte mercury mine, OR. Applied Geochemistry, 61: 284-293. doi:10.1016/j.apgeochem.2015.06.011.

Ekstrom EB, Morel FMM, and Benoit JM. 2003. Mercury methylation independent of the acetyl-coenzyme A pathway in sulfate-reducing bacteria. Applied and Environmental Microbiology, 69: 5414-5422. PMID:12957930. doi:10.1128/AEM.69.9.5414-5422.2003.

Enrich-Prast A, Meirelles-Pereira F, and Esteves FA. 2004. Development of periphytic bacteria associated with detritus of the Amazonian aquatic macrophyte Oryza glumaepatula. Amazoniana, 18: 81-93.

Eriksen HH, and Perrez FX. 2014. The Minamata Convention: a comprehensive response to a global problem. Review of European, Comparative and International Environmental Law, 23: 195-210. doi:10.1111/reel.12079.

Evers DC, Keane S, Basu N, and Buck D. 2016. Evaluating the effectiveness of the Minamata Convention on Mercury: principles and recommendations for next steps. Science of the Total Environment, 569: 888-903. PMID:27425440. doi:10.1016/j.scitotenv.2016.05.001.

Faganeli J, Hines ME, Covelli S, Emili A, and Giani M. 2012. Mercury in lagoons: an overview of the importance of the link between geochemistry and biology. Estuarine, Coastal, and Shelf Science, 113: 126-132. doi:10.1016/j.ecss.2012.08.021.

Figueiredo NL, Canário J, O'Driscoll NJ, Duarte A, and Carvalho C. 2016. Aerobic mercury-resistant bacteria alter mercury speciation and retention in the Tagus Estuary (Portugal). Ecotoxicology and Environmental Safety, 124: 60-67. PMID:26461264. doi:10.1016/j.ecoenv.2015.10.001.

Fitzgerald WF, Lamborg CH, and Hammerschmidt CR. 2007. Marine biogeochemical cycling of mercury. Chemical Reviews, 107: 641-662. PMID:17300143. doi:10.1021/cr050353m.

Fleck JA, Gill GA, Bergamaschi BA, Kraus TEC, Downing BD, and Alpers CN. 2014. Concurrent photolytic degradation of aqueous methylmercury and dissolved organic matter. Science of the Total Environment, 484: 263-275. PMID:23642571. doi:10.1016/j.scitotenv.2013.03.107.

Fleming EJ, Mack EE, Green PG, and Nelson DC. 2006. Mercury methylation from unexpected sources: molybdate-inhibited freshwater sediments and an iron-reducing bacterium. Applied and Environmental Microbiology, 72: 457-464. PMID:16391078. doi:10.1128/AEM.72.1.457-464.2006.

French TD, Houben AJ, SDesforges J-PW, Kimpe LE, Kokelj SV, Poulain A, et al. 2014. Dissolved organic carbon thresholds affect mercury bioaccumulation in Arctic Lakes. Environmental Science \& Technology, 48: 3162-3168. PMID:24524759. doi:10.1021/es403849d.

Furutani A, and Rudd JWM. 1980. Measurement of mercury methylation in lake water and sediment samples. Applied and Environmental Microbiology, 40: 770-776. 
Gilmour CC, and Henry EA. 1991. Mercury methylation in aquatic systems affected by acid deposition. Environmental Pollution, 71: 131-169. PMID:15092118. doi:10.1016/0269-7491(91)90031-Q.

Gilmour CC, Henry EA, and Mitchell R. 1992. Sulfate stimulation of mercury methylation in freshwater sediments. Environmental Science \& Technology, 26: 2281-2287. doi:10.1021/es00035a029.

Gilmour CC, Riedel GS, Ederington MC, Bell JT, Benoit JM, Gill GA, et al. 1998. Methylmercury concentrations and production rates across a trophic gradient in the northern Everglades. Biogeochemistry, 40: 327-345. doi:10.1023/A:1005972708616.

Gilmour CC, Podar M, Bullock AL, Mitchell Grahan A, Brown S, Somenahally AC, et al. 2013. Mercury methylation by novel microorganisms from new environments. Environmental Science \& Technology, 47: 11810-11820. PMID:24024607. doi:10.1021/es403075t.

Gionfriddo CM, Tate MT, Wick RR, Schultz MB, Zemla A, Thelen MP, et al. 2016. Microbial mercury methylation in Antarctic sea ice. Nature Microbiology, 1: 16127. doi:10.1038/nmicrobiol.2016.127.

Girard C, Leclerc M, and Amyot M. 2016. Photodemethylation of methylmercury in eastern Canadian arctic thaw pond and lake ecosystems. Environmental Science \& Technology, 50: 3511-3520. PMID:26938195. doi:10.1021/acs.est.5b04921.

Goñi-Urriza M, Corsellis Y, Lanceleur L, Tessier E, Gury J, Monperrus M, et al. 2015. Relationships between bacterial energetic metabolims, mercury methylation potential, and $\mathrm{hgcA} / \mathrm{hgcB}$ gene expression in Desulfovibrio dechloroacetivorans BerOc1. Environmental Science and Pollution Research, 22: 13764-13771. doi:10.1007/s11356-015-4273-5.

Gordon J, Quinton W, Branfireun BA, and Loefeldt D. 2016. Mercury and methylmercury biogeochemistry in a thawing permafrost wetland complex, Northwest Territories, Canada. Hydrological Processes, 30(20): 3627-3638. doi:10.1002/hyp.10911.

Graham AM, Aiken GR, and Gilmour CC. 2013. Effect of dissolved organic matter source and character on microbial Hg methylation in Hg-S-DOM solutions. Environmental Science \& Technology, 47: 5746-5754. PMID:23634978. doi:10.1021/es400414a.

Graham EB, Knelman JE, Gabor RS, Schooler S, McKnight DM, and Nemergut DR. 2016. Dissolved organic matter and inorganic mercury loadings increase methylmercury production, Clostridia abundance, and recalcitrant organic matter processing in oligotrophic sediments. bioRxiv. doi:10.1101/ 072017.

Grandjean P, Murata K, Budtz-Jørgensen E, and Weihe P. 2004. Cardiac autonomic activity in methylmercury neurotoxicity: 14-year follow-up of a Faroese birth cohort. The Journal of Pediatrics, 144: 169-176. PMID:14760255. doi:10.1016/j.jpeds.2003.10.058.

Gray JE, and Hines ME. 2009. Biogeochemical mercury methylation influenced by reservoir eutrophication, Salmon Falls Creek Reservoir, Idaho, USA. Chemical Geology, 258: 157-167. doi:10.1016/j. chemgeo.2008.09.023.

Grégoire DS, and Poulain AJ. 2014. A little bit of light goes a long way: the role of phototrophs on mercury cycling. Metallomics, 6: 396-407. doi:10.1039/c3mt00312d.

Guédron S, Huguet L, Vignati DAL, Liu B, Gimbert F, Ferrari BJD, et al. 2012. Tidal cycling of mercury and methylmercury between sediments and water column in the Venice Lagoon (Italy). Marine Chemistry, 130-131: 1-11. doi:10.1016/j.marchem.2011.12.003. 
Hall BD, and St. Louis VL. 2004. Methylmercury and total mercury in plant litter decomposing in upland forests and flooded landscapes. Environmental Science \& Technology, 38: 5010-5021. PMID:15506193. doi:10.1021/es049800q.

Hall BD, St. Louis VL, and Bodaly RA. 2004. The stimulation of methylmercury production by decomposition of flooded birch leaves and jack pine needles. Biogeochemistry, 68: 107-129. doi:10.1023/B:BIOG.0000025745.28447.8b.

Hall BD, St. Louis VL, Rolfhus KR, Bodaly RA, Beaty KG, Paterson MJ, et al. 2005. The impact of reservoir creation on the biogeochemical cycling of methyl and total mercury in boreal upland forests. Ecosystems, 8: 248-266. doi:10.1007/s10021-003-0094-3.

Hall BD, Aiken GR, Krabbenhoft DP, Marvin-Dipasquale M, and Swarzenski CM. 2008. Wetlands as principal zones of methylmercury production in Southern Louisiana and the Gulf of Mexico region. Environmental Pollution, 154: 124-134. PMID:18242808. doi:10.1016/j. envpol.2007.12.017.

Hamelin S, Planas D, and Amyot M. 2015a. Spatio-temporal variations in biomass and mercury concentrations of epiphytic biofilms and their host in a large river wetlands (Lake St. Pierre, QC, Canada). Environmental Pollution, 197: 221-230. doi:10.1016/j.envpol.2014.11.007.

Hamelin S, Planas D, and Amyot M. 2015b. Mercury methylation and demethylation by periphyton biofilms and their host in a fluvial wetland of the St. Lawrence River (QC, Canada). Science of the Total Environment, 512-513: 464-471. doi:10.1016/j.scitotenv.2015.01.040.

Hamelin S, Amyot M, Barkay T, Wang YX, and Planas D. 2011. Methanogens: principal methylators of mercury in lake periphyton. Environmental Science \& Technology, 45: 7693-7700. PMID:21875053. doi:10.1021/es2010072.

Hammerschmidt CR, and Fitzgerald WF. 2004. Geochemical controls on the production and distribution of methylmercury in near-shore marine sediments. Environmental Science \& Technology, 38: 1487-1495. PMID:15046351. doi:10.1021/es034528q.

Hammerschmidt CR, and Fitzgerald WF. 2006a. Photodecomposition of methylmercury in an Arctic Alaskan lake. Environmental Science \& Technology, 40: 1212-1216. doi:10.1021/es0513234.

Hammerschmidt CR, and Fitzgerald WF. 2006b. Methylmercury cycling in sediments on the continental shelf of southern New England. Geochimica et Cosmochimica Acta, 70: 918-930. doi:10.1016/j.gca.2005.10.020.

Harris RC, Rudd JWM, Almyot M, Babiarz CL, Beaty KG, Blanchfield PJ, et al. 2007. Wholeecosystem study shows rapid fish-mercury response to changes in mercury deposition. Proceedings of the National Academy of Sciences of the United States of America, 104: 16586-16591. PMID:17901207. doi:10.1073/pnas.0704186104.

Hayashi K, Kawai S, Ohno T, and Maki Y. 1977. Photo methylation of inorganic mercury by aliphatic $\alpha$-amino-acids. Journal of the Chemical Society, Chemical Communications, 5: 158-159. doi:10.1039/ C39770000158.

Heim WA, Coale KH, Stephenson M, Choe K-Y, Gill G, and Foe C. 2007. Spatial and habitat-based variations in total and methyl mercury concentrations in surficial sediments in the San Francisco BayDelta. Environmental Science \& Technology, 41: 3501-3507. PMID:17547170. doi:10.1021/es0626483. 
Heimbürger L-E, Cossa D, Marty J-C, Migon C, Averty B, Dufour A, et al. 2010. Methyl mercury distributions in relation to the presence of nano- and picophytoplankton in an oceanic water column (Ligurian Sea, North-western Mediterranean). Geochimica et Cosmochimica Acta, 74: 5549-5559. doi:10.1016/j.gca.2010.06.036.

Heyes A, Mason RP, Kim E-H, and Sunderland E. 2006. Mercury methylation in estuaries: Insights from using measuring rates using stable mercury isotopes. Marine Chemistry, 102: 134-147. doi:10.1016/j.marchem.2005.09.018.

Hightower JM. 2009. Diagnosis: mercury. Island Press, Washington, D.C. 328 p.

Hines ME, Poitras EN, Covelli S, Faganeli J, Emili A, Žižek S, et al. 2012. Mercury methylation and demethylation in $\mathrm{Hg}$-contaminated lagoon sediments (Marano and Grado Lagoon, Italy). Estuarine, Coastal, and Shelf Science, 113: 85-95. doi:10.1016/j.ecss.2011.12.021.

Hintelmann H. 2010. Organomercurials. Their formation and pathways in the environment. Metal Ions in Life Sciences, 7: 365-401. PMID:20877813. doi:10.1039/9781849730822-00365.

Hintelmann H, Keppel-Jones K, and Evans RD. 2000. Constants of mercury methylation and demethylation rates in sediments and comparison of tracer and ambient mercury availability. Environmental Toxicology and Chemistry, 19: 2204-2211. doi:10.1002/etc.5620190909.

Hoggarth CGJ, Mitchell CPJ, and Hall BD. 2015. Mercury methylation in high and low-sulphate impacted wetland ponds within the prairie pothole region of North America. Environmental Pollution, 205: 269-277. PMID:26099458. doi:10.1016/j.envpol.2015.05.046.

Hollweg TA, Gilmour CC, and Mason RP. 2010. Mercury and methylmercury cycling in sediments of the mid-Atlantic continental shelf and slope. Limnology and Oceanography, 55: 2703-2722. doi:10.4319/lo.2010.55.6.2703.

Hsu-Kim H, Kucharzyk KH, Zhang T, and Deschusses MA. 2013a. Mechanisms regulating mercury bioavailability for methylating microorganisms in the aquatic environment: a critical review. Environmental Science \& Technology, 47: 2441-2456. doi:10.1021/es304370g.

Hsu-Kim H, Kucharzyk KH, Zhang T, and Deshusses MA. 2013b. Mechanisms regulating mercury bioavailability for methylating microorganisms in the aquatic environment: a critical review. Environmental Science \& Technology, 47: 2441-2456. doi:10.1021/es304370g.

Huguet L, Castelle S, Schäfer J, Blanc G, Maury-Brachet R, Reynouard C, et al. 2010. Mercury methylation rates of biofilm and plankton microorganisms from a hydroelectric reservoir in French Guiana. The Science of the Total Environment, 408: 1338-1348. PMID:19914680. doi:10.1016/j. scitotenv.2009.10.058.

Intergovernmental Panel on Climate Change (IPCC). 2014. Climate Change 2014: Synthesis Report. Contribution of Working Groups I, II and III to the Fifth Assessment Report of the Intergovernmental Panel on Climate Change. $151 \mathrm{p}$.

Jansson JK, and Tas N. 2014. The microbial ecology of permafrost. Nature Reviews Microbiology, 12: 414-425. PMID:24814065. doi:10.1038/nrmicro3262.

Jeremiason JD, Engstrom DR, Swain EB, Nater EA, Johnson BM, Almendinger JE, et al. 2006. Sulfate addition increases methylmercury production in an experimental wetland. Environmental Science \& Technology, 40: 3800-3806. PMID:16830545. doi:10.1021/es0524144. 
Johnson NW, Mitchell CPJ, Engstrom DR, Bailey LT, Coleman Wasik JK, and Berndt ME. 2016. Methylmercury production in a chronically sulfate-impacted sub-boreal wetland. Environmental Science: Processes and Impacts, 18(6): 725-734. doi:10.1039/c6em00138f.

Johnson WP, Swanson N, Black B, Rudd A, Carling G, Fernandez DP, et al. 2015. Total- and methylmercury concentrations and methylation rates across the freshwater to hypersaline continuum of the Great Salt Lake, Utah, USA. Science of the Total Environment, 511: 489-500. PMID:25576792. doi:10.1016/j.scitotenv.2014.12.092.

Jonsson S, Skyllberg UL, Nilsson MB, Westlund P-O, Shchukarev A, Lundberg E, et al. 2012. Mercury methylation rates for geochemically relevant $\mathrm{Hg}^{\mathrm{II}}$ species in sediments. Environmental Science \& Technology, 46: 11653-11659. PMID:23017152. doi:10.1021/es3015327.

Jonsson S, Skyllberg U, Nilsson MB, Lundberg E, Andersson A, and Björn E. 2014. Differentiated availability of geochemical mercury pools controls methylmercury levels in estuarine sediment and biota. Nature Communications, 5: 4624. doi:10.1038/ncomms5624.

Kaschak E, Knopf B, Petersen JH, Bings NH, and König H. 2014. Biotic methylation of mercury by intestinal and sulfate-reducing bacteria and their potential role in mercury accumulation in the tissue of the soil-living Eisenia foetida. Soil Biology and Biochemistry, 69: 202-211. doi:10.1016/j. soilbio.2013.11.004.

Kelly CA, Rudd JWM, Bodaly RA, Roulet NT, St. Louis VL, Heyes A, et al. 1997. Increases in fluxes of greenhouse gases and methyl mercury following flooding of an experimental reservoir. Environmental Science \& Technology, 31: 1334-1344. doi:10.1021/es9604931.

Kelly CA, Rudd JWM, and Holoka MH. 2003. Effect of pH on mercury uptake in an aquatic bacterium: implications for $\mathrm{Hg}$ cycling. Environmental Science \& Technology, 37: 2941-2946. PMID:12875398. doi:10.1021/es026366o.

Kelly EN, Schindler DW, St. Louis VL, Donald DB, and Vladicka KE. 2006. Forest fire increases mercury accumulation by fishes via food web restructuring and increased mercury inputs. Proceedings of the National Academy of Science, 103: 19380-19385. doi:10.1073/pnas.0609798104.

Kerin EJ, Gilmour CC, Roden E, Suzuki MT, Coates JD, and Mason RP. 2006. Mercury methylation by dissimilatory iron-reducing bacteria. Applied and Environmental Microbiology, 72: 7919-7921. PMID:17056699. doi:10.1128/AEM.01602-06.

Kerry A, Welbourn PM, Prucha B, and Mi G. 1991. Mercury methylation by sulphate-reducing bacteria from sediments of an acid stressed lake. Water Air and Soil Pollution, 56: 565-575. doi:10.1007/BF00342300.

Keucharzyk K, Deshusses MA, Porter K, and Hsu-Kim H. 2015. Relative contributions of mercury bioavailability and microbial growth rate on net methylmercury production by anaerobic mixed cultures. Environmental Science: Processes and Impacts, 17: 1568-1577. doi:10.1039/C5EM00174A.

King JK, Saunders FM, Lee RF, and Jahnke RA. 1999. Coupling mercury methylation rates to sulfate reduction rates in marine sediments. Environmental Toxicology and Chemistry, 18: 1362-1369. doi:10.1002/etc.5620180704.

King JK, Kostka JE, Frischer ME, and Saunders FM. 2000. Sulfate-reducing bacteria methylate mercury at variable rates in pure culture and in marine sediments. Applied and Environmental Microbiology, 66: 2430-2437. PMID:10831421. doi:10.1128/AEM.66.6.2430-2437.2000. 
Kirk JL, Lehnherr I, Andersson M, Braune BM, Chan L, Dastoor AP, et al. 2012. Mercury in Arctic marine ecosystems: sources, pathways and exposure. Environmental Research, 119: 64-87. PMID:23102902. doi:10.1016/j.envres.2012.08.012.

Korthals ET, and Winfrey MR. 1987. Seasonal and spatial variations in mercury methylation and demethylation in an oligotrophic lake. Applied and Environmental Microbiology, 53: 2397-2404. PMID:16347460.

Lambertsson L, and Nilsson M. 2006. Organic material: the primary control on mercury methylation and ambient methyl mercury concentrations in estuarine sediments. Environmental Science \& Technology, 40: 1822-1829. PMID:16570603. doi:10.1021/es051785h.

Lehnherr I, and St. Louis VL. 2009. Importance of ultraviolet radiation in the photodemethylation of methylmercury in freshwater ecosystems. Environmental Science \& Technology, 43: 5692-5698. PMID:19731664. doi:10.1021/es9002923.

Lehnherr I, St. Louis VL, Hintelmann H, and Kirk JL. 2011. Methylation of inorganic mercury in polar marine waters. Nature Geoscience, 4: 298-302. doi:10.1038/ngeo1134.

Lehnherr I, St. Louis VL, and Kirk JL. 2012. Methylmercury cycling in high Arctic wetland ponds: controls on sedimentary production. Environmental Science \& Technology, 46: 10523-10531. PMID:22799567. doi:10.1021/es300577e.

Li Y, and Cai Y. 2013. Progress in the study of mercury methylation and demethylation in aquatic environments. Chinese Science Bulletin, 58: 177-185. doi:10.1007/s11434-012-5416-4.

Liem-Nguyen V, Jonsson S, Skyllberg UL, Nilsson MB, Andersson A, Lundberg E, et al. 2016. Effects of nutrient loading and mercury chemical speciation on the formation and degradation of methylmercury in estuarine sediment. Environmental Science \& Technology, 50: 6983-6990. PMID:27258391. doi:10.1021/acs.est.6b01567.

Liu B, Schaider LA, Mason RP, Shine JP, Rabalais NN, and Senn DB. 2015. Controls on methylmercury accumulation in northern Gulf of Mexico sediments. Estuarine, Coastal and Shelf Science, 159: 50-59. doi:10.1016/j.ecss.2015.03.030.

Liu Y-R, Dong J-X, Han L-L, Zheng Y-M, and He J-Z. 2016. Influence of rice straw amendment on mercury methylation and nitrification in paddy soils. Environmental Pollution, 209: 53-59. PMID:26629646. doi:10.1016/j.envpol.2015.11.023.

Lu X, Liu Y, Johs A, Zhao L, Wang T, Yang Z, et al. 2016. Anaerobic mercury methylation and demethylation by Geobacter bemidjiensis Bem. Environmental Science \& Technology, 50: 4366-4373. PMID:27019098. doi:10.1021/acs.est.6b00401.

Malcolm EG, Schaefer JK, Ekstrom EB, Tuit CB, Jayakumar A, Park H, et al. 2010. Mercury methylation in oxygen deficient zones of the oceans: no evidence for the predominance of anaerobes. Marine Chemistry, 122: 11-19. doi:10.1016/j.marchem.2010.08.004.

Martín-Doimeadios RCR, Tessier E, Amouroux D, Guyoneaud R, Duran R, Caumette P, et al. 2004. Mercury methylation/demethylation and volatilization pathways in estuarine sediment slurries using species-specific enriched stable isotopes. Marine Chemistry, 90: 107-123. doi:10.1016/j. marchem.2004.02.022. 
Marvin-DiPasquale M, Agee JL, McGowan C, Oremland RS, Thomas M, Krabbenhoft DP, et al. 2000. Methyl-mercury degradation pathways: a comparison among three mercury-impacted ecosystems. Environmental Science \& Technology, 34: 4908-4916. doi:10.1021/es0013125.

Marvin-DiPasquale MC, Agee JL, Bouse RM, and Jaffe BE. 2003. Microbial cycling of mercury in contaminated pelagic and wetland sediments of San Pablo Bay, California. Environmental Geology, 43: $260-267$.

Marvin-DiPasquale M, Windham-Myers L, Agee JL, Kakouros E, Kieu LH, Fleck JA, et al. 2014. Methylmercury production in sediment from agricultural and non-agricultural wetlands in the Yolo Bypass, California, USA. Science of the Total Environment, 484: 288-299. PMID:24188689. doi:10.1016/j.scitotenv.2013.09.098.

Mason RP, Fitzgerald WF, Hurley JP, Hanson AK Jr, Donaghay PL, and Sieburth JM. 1993. Mercury biogeochemical cycling in a stratified estuary. Limnology and Oceanography, 38: 1227-1241. doi:10.4319/lo.1993.38.6.1227.

Matilainen T. 1995. Involvement of bacteria in methylmercury formation in anaerobic lake waters. Water, Air, and Soil Pollution, 80: 757-764. doi:10.1007/BF01189727.

Matilainen T, and Verta M. 1995. Mercury methylation and demethylation in aerobic surface waters. Canadian Journal of Fisheries and Aquatic Sciences, 52: 1597-1608. doi:10.1139/f95-753.

Mazrui N, Jonsson S, Thora S, Zhao J, and Mason RP. 2016. Enhanced availability of mercury bound to dissolved organic matter for methylation in marine sediments. Geochimica et Cosmochimica Acta, 194: 153-162. doi:10.1016/j.gca.2016.08.019.

Merritt KA, and Amirbahman A. 2009. Mercury methylation dynamics in estuarine and coastal marine environments—a critical review. Earth-Science Reviews, 96: 54-66. doi:10.1016/j.earscirev.2009.06.002.

Miskimmin BM, Rudd JWM, and Kelly CA. 1992. Influence of dissolved organic carbon, pH, and microbial respiration rates of mercury methylation and demethylation in lake water. Canadian Journal of Fisheries and Aquatic Sciences, 49: 17-22. doi:10.1139/f92-002.

Mitchell CPJ, and Gilmour CC. 2008. Methylmercury production in a Chesapeake Bay salt marsh. Journal of Geophysical Research-Biogeosciences, 113: G00C04. doi:10.1029/2008JG000765.

Mitchell CPJ, Branfireun BA, and Kolka RK. 2008a. Total mercury and methylmercury dynamics in upland-peatland watersheds during snowmelt. Biogeochemistry, 90: 225-241. doi:10.1007/ s10533-008-9246-z.

Mitchell CPJ, Branfireun BA, and Kolka RK. 2008b. Assessing sulfate and carbon controls on net methylmercury production in peatlands: an in situ mesocosm approach. Applied Geochemistry, 23: 503-518. doi:10.1016/j.apgeochem.2007.12.020.

Monperrus M, Tessier E, Amouroux D, Leynaert A, Huonnie P, and Donald OFX. 2007a. Mercury methylation, demethylation and reduction rates in coastal and marine surface waters of the Mediterranean Sea. Marine Chemistry, 107: 49-63. doi:10.1016/j.marchem.2007.01.018.

Monperrus M, Tessier E, Point D, Vidimova K, Amouroux D, Guyoneaud R, et al. 2007b. The biogeochemistry of mercury at the sediment-water interface in the Thau Lagoon. 2. Evaluation of mercury methylation potential in both surface sediment and the water column. Estuarine, Coastal and Shelf Science, 72: 485-496. doi:10.1016/j.ecss.2006.11.014. 
Nagase H, Ose Y, Sato T, and Ishikawa T. 1982. Methylation of mercury by humic substances in an aquatic environment. Science of the Total Environment, 25: 133-142. doi:10.1016/0048-9697(82) 90082-1.

Ndu U, Mason RP, Zhang H, Lin S, and Visscher PT. 2012. Effect of inorganic and organic ligands on the bioavailability of methylmercury as determined by using a mer-lux bioreporter. Applied and Environmental Microbiology, 78: 7276-7282. PMID:22865079. doi:10.1128/ AEM.00362-12.

Normile D. 2013. In Minamata, mercury still divides. Science, 341: 1446-1447. PMID:24072902. doi:10.1126/science.341.6153.1446.

Olson BH, and Cooper RC. 1974. In situ methylation of mercury in estuarine sediments. Nature, 252: 682-683. doi:10.1038/252682b0.

Oremland RS, Miller LG, Dowdle P, Connell T, and Barkay T. 1995. Methylmercury oxidative degradation potentials in contaminated and pristine sediments of the Carson River, Nevada. Applied and Environmental Microbiology, 61: 2745-2753. PMID:16535081.

Ortiz VL, Mason RP, and Evan Ward J. 2015. An examination of the factors influencing mercury and methylmercury particulate distributions, methylation and demethylation rates in laboratorygenerated marine snow. Marine Chemistry, 177: 753-762. PMID:26644635. doi:10.1016/j. marchem.2015.07.006.

Ouddane B, Mikac N, Cundy AB, Quillet L, and Fischer JC. 2008. A comparative study of mercury distribution and methylation in mudflats from two macrotidal estuaries: The Seine (France) and the Medway (United Kingdom). Applied Geochemistry, 23: 618-631. doi:10.1016/j. apgeochem.2007.11.001.

Pak K-R, and Bartha R. 1998. Mercury methylation and demethylation in anoxic lake sediments and by strictly anaerobic bacteria. Applied and Environmental Microbiology, 64: 1013-1017. PMID:16349509.

Parks JM, Johs A, Podar M, Bridou R, Hurt JRA, Smith S, et al. 2013. The genetic basis for bacterial mercury methylation. Science, 339: 1332-1335. PMID:23393089. doi:10.1126/ science. 1230667.

Peng X, Liu F, Wang W-X, and Ye Z. 2012. Reducing total mercury and methylmercury accumulation in rice grains through water management and deliberate selection of rice cultivars. Environmental Pollution, 162: 202-208. PMID:22243865. doi:10.1016/j.envpol.2011.11.024.

Pennanen T, Fritze H, Vanhala P, Kiikkila O, Neuvonen S, and Baath E. 1998. Structure of a microbial community in soil after prolonged addition of low levels of simulated acid rain. Applied and Environmental Microbiology, 64: 2173-2180. PMID:9603831.

Perrot V, Jimenez-Moreno M, Berails S, Epov VN, Monperrus M, and Amouroux D. 2013. Successive methylation and demethylation of methylated mercury species (MeHg and $\mathrm{DMeHg}$ ) induce mass dependent fractionation of mercury isotopes. Chemical Geology, 355: 153-162. doi:10.1016/j. chemgeo.2013.07.011.

Podar M, Gilmour CC, Brandt CC, Soren A, Brown SD, Crable BR, et al. 2015. Global prevalence and distribution of genes and microorganisms involved in mercury methylation. Science Advances, 1: e1500675. PMID:26601305. doi:10.1126/sciadv.1500675. 
Pongratz R, and Heumann KG. 1998. Production of methylated mercury and lead by polar macroalgae-a significant natural source for atmospheric heavy metals in clean room compartments. Chemosphere, 36: 1935-1946. doi:10.1016/S0045-6535(97)10078-9.

Pongratz R, and Heumann KG. 1999. Production of methylated mercury, lead, and cadmium by marine bacteria as a significant natural source for atmospheric heavy metals in polar regions. Chemosphere, 39: 89-102. doi:10.1016/S0045-6535(98)00591-8.

Qiu G, Feng X, Li P, Wang S, Li G, Shang L, et al. 2008. Methylmercury accumulation in rice (Oryza sativa L.) grown at abandoned mercury mines in Guizhou, China. Journal of Agriculture and Food Chemistry, 56: 2465-2468. doi:10.1021/jf073391a.

Ramlal PS, Rudd JWM, and Hecky RE. 1986. Methods for measuring specific rates of mercury methylation and degradation and their use in determining factors controlling net rates of mercury methylation. Applied and Environmental Microbiology, 51: 110-114. PMID:16346959.

Ramlal PS, Kelly CA, Rudd JWM, and Furutani A. 1993. Sites of methylmercury production in remote Canadian shield lakes. Canadian Journal of Fisheries and Aquatic Sciences, 50: 972-979. doi:10.1139/f93-112.

Ravichandran M. 2004. Interactions between mercury and dissolved organic matter-a review. Chemosphere, 55: 319-331. PMID:14987930. doi:10.1016/j.chemosphere.2003.11.011.

Regnell O. 1994. The effect of $\mathrm{pH}$ and dissolved oxygen levels on methylation and partitioning of mercury in freshwater model systems. Environmental Pollution, 84: 7-13. PMID:15091718. doi:10.1016/0269-7491(94)90064-7.

Rolfhus KR, Hurley JP, Bodaly RAD, and Perrine G. 2015. Production and retention of methylmercury in inundated boreal forest soils. Environmental Science \& Technology, 49: 3482-3489. PMID:25668143. doi:10.1021/es505398z.

Rothenberg SE, Feng X, Dong B, Shang L, Yin R, and Yuan X. 2011. Characterization of mercury species in brown and white rice (Oryza sativa L.) grown in water-saving paddies. Environmental Pollution, 159: 1283-1289. PMID:21349615. doi:10.1016/j.envpol.2011.01.027.

Rothenberg SE, Windham-Myers L, and Creswell JE. 2014. Rice methylmercury exposure and mitigation: a comprehensive review. Environmental Research, 133: 407-423. PMID:24972509. doi:10.1016/j.envres.2014.03.001.

Rudd JWM, Turner MA, Furutani A, Swick AL, and Townsend BE. 1983. The English-Wabigoon river system: I. A synthesis of recent research with a view towards mercury amelioration. Canadian Journal of Fisheries and Aquatic Sciences, 40: 2206-2217. doi:10.1139/f83-257.

Sando SK, Krabbenhoft DP, Johnson KM, Lundgrean RF, and Emerson DG. 2007. Mercury and methylmercury in water and bottom sediments of wetlands at Lostwood National Wildlife Refuge, North Dakota, 2003-2004. USGS Scientific Investigations Report 2007-5219. 74 p.

Schaefer JK, Rocks SS, Zheng W, Liang L, Gu B, and Morel FMM. 2011. Active transport, substrate specificity, and methylation of $\mathrm{Hg}$ (II) in anaerobic bacteria. Proceedings of the National Academy of Science, 108: 8714-8719. doi:10.1073/pnas.1105781108. 
Schindler DW. 1997. Widespread effects of climatic warming on freshwater ecosystems in North America. Hydrological Processes, 11: 1043-1067. doi:10.1002/(SICI)1099-1085(19970630)11: $8<1043::$ AID-HYP517>3.0.CO;2-5.

Selifonova O, Burlage R, and Barkay T. 1993. Bioluminescent sensors for detection of bioavailable $\mathrm{Hg}(\mathrm{II})$ in the environment. Applied and Environmental Microbiology, 59: 3083-3090. PMID:8215378.

Sellers P, Kelly CA, Rudd JWM, and Machutchon A. 1996. Photodegradation of methylmercury in lakes. Nature, 380: 694-697. doi:10.1038/380694a0.

Selvendrian P, Driscoll CT, Bushey JT, and Montesdeoca MR. 2008. Wetland influence on mercury fate and transport in a temperate forested watershed. Environmental Pollution, 154: 46-55. doi:10.1016/j.envpol.2007.12.005.

Si Y, Zou Y, Liu X, Si X, and Mao J. 2015. Mercury methylation coupled to iron reduction by dissimilatory iron-reducing bacteria. Chemosphere, 122: 206-212. PMID:25496739. doi:10.1016/j. chemosphere.2014.11.054.

Silva LOB, da Silva DG, Leao DJ, Matos GD, and Ferreira SLC. 2012. Slurry sampling for the determination of mercury in rice using cold vapor atomic absorption spectrometry. Food Analytical Methods, 5: 1289-1295. doi:10.1007/s12161-012-9371-0.

Singer MB, Harrison LR, Donovan PM, Blum JD, and Marvin-Dipasquale M. 2016. Hydrologic indicators of hot spots and hot moments of mercury methylation potential along river corridors. Science of the Total Environment, 568: 697-711. doi:10.1016/j.scitotenv.2016.03.005.

Sizmur T, Canário J, Edmonds S, Godfrey A, and O’Driscoll N. 2013. The polychaete worm Nereis diversicolor increases mercury lability and methylation in intertidal mudflats. Environmental Toxicology and Chemistry, 32: 1888-1895. PMID:23633443. doi:10.1002/etc.2264.

Soerensen AL, Jacob DJ, Schartup AT, Fisher JA, Lehnherr I, St. Louis VL, et al. 2016. A mass balance budget for mercury and methylmercury in the Arctic Ocean. Global Biogeochemical Cycles, 30: 560-575. doi:10.1002/2015GB005280.

Sonke JE, Heimbürger L-E, and Dommergue A. 2013. Mercury biogeochemistry: paradigm shifts, outstanding issues and research needs. Comptes Rendus Geoscience, 345: 213-224. doi:10.1016/j. crte.2013.05.002.

Spry DJ, and Wiener JG. 1991. Metal bioavailability and toxicity to fish in low-alkalinity lakes: a critical review. Environmental Pollution, 71: 243-304. PMID:15092121. doi:10.1016/0269-7491(91) 90034-T.

St. Louis VL, Hintelmann H, Graydon JA, Kirk JL, Barker J, Dimock B, et al. 2007. Methylated mercury species in Canadian high Arctic marine surface waters and snowpacks. Environmental Science \& Technology, 41: 6433-6441. PMID:17948790. doi:10.1021/es070692s.

St. Louis VL, Rudd JWM, Kelly CA, Beaty KG, Bloom NS, and Flett RJ. 1994. Importance of wetlands as sources of methyl mercury to boreal forest ecosystems. Canadian Journal of Fisheries And Aquatic Sciences, 51: 1065-1076. doi:10.1139/f94-106.

St. Louis VL, Rudd JWM, Kelly CA, Beaty KG, Flett RJ, and Roulet NT. 1996. Production and loss of methylmercury and loss of total mercury from boreal forest catchments containing different types of wetlands. Environmental Science \& Technology, 30: 2719-2729. doi:10.1021/es950856h. 
St. Louis VL, Rudd JWM, Kelly CA, Bodaly RA, and Harris R. 2004. The rise and fall of mercury methylation in an experimental reservoir. Environmental Science \& Technology, 38: 1348-1358. PMID:15046335. doi:10.1021/es034424f.

Stern GA, Macdonald RW, Outridge PM, Wilson S, Chételat J, Cole A, et al. 2012. How does climate change influence arctic mercury? Science of the Total Environment, 414: 22-42. PMID:22104383. doi:10.1016/j.scitotenv.2011.10.039.

Strickman RJ, and Mitchell CPJ. 2017. Accumulation and translocation of methylmercury and inorganic mercury in Oryza sativa: An enriched isotope tracer study. Science of the Total Environment, 574: 1415-1423. doi:10.1016/j.scitotenv.2016.08.068.

Sunderland EM, Krabbenhoft DP, Moreau JW, Strode SA, and Landing WM. 2009. Mercury sources, distribution, and bioavailability in the North Pacific Ocean: insights from data and models. Global Biogeochemical Cycles, 23: GB2010. doi:10.1029/2008GB003425.

Takaoka S, Fujino T, Hotta N, Ueda K, Hanada M, Tajiri M, et al. 2014. Signs and symptoms of methylmercury contamination in a First Nations community in Northwestern Ontario, Canada. Science of the Total Environment, 468-469: 950-957. doi:10.1016/j.scitotenv.2013.09.015.

Tan SW, Meiller JC, and Mahaffey KR. 2009. The endocrine effects of mercury in humans and wildlife. Critical Reviews in Toxicology, 39(3): 228-269. doi:10.1080/10408440802233259.

Tjerngren I, Karlsson T, Bjorn E, and Skyllberg U. 2012a. Potential Hg methylation and MeHg demethylation rates related to the nutrient status of different boreal wetlands. Biogeochemistry, 108: 335-350. doi:10.1007/s10533-011-9603-1.

Tjerngren I, Meili M, Bjorn E, and Skyllberg U. 2012b. Eight boreal wetlands as sources and sinks for methyl mercury in relation to soil acidity, C/N ratio, and small-scale flooding. Environmental Science \& Technology, 46: 8052-8060. doi:10.1021/es300845x.

Todorova SG, Driscoll CT, Matthews DA, Effler SW, Hines ME, and Henry EA. 2009. Evidence for regulation of monomethyl mercury by nitrate in a seasonally stratified, eutrophic lake. Environmental Science \& Technology, 43: 6572-6578. PMID:19764219. doi:10.1021/es900887b.

Tsubaki T, and Irukayama K. 1977. Minamata disease. Methylmercury poisoning in Minamata and Niigata, Japan. North-Holland Publishing Company, Amsterdam, The Netherlands. 317 p.

Ullrich SM, Tanton TW, and Abdrashitova SA. 2001. Mercury in the aquatic environment: a review of factors affecting methylation. Critical Reviews in Environmental Science and Technology, 31: 241-293. doi:10.1080/20016491089226.

Wang X, Zhihong Y, Li B, Huang L, Meng M, Shi J, et al. 2014. Growing rice aerobically markedly decreases mercury accumulation by reducing both $\mathrm{Hg}$ bioavailability and the production of MeHg. Environmental Science \& Technology, 48: 1878-1885. PMID:24383449. doi:10.1021/ es4038929.

Waples JS, Nagy KL, Aiken GR, and Ryan JN. 2005. Dissolution of cinnabar (HgS) in the presence of natural organic matter. Geochimica et Cosmochimica Acta, 69: 1575-1588. doi:10.1016/j. gca.2004.09.029. 
Warner KA, Roden EE, and Bonzongo J-C. 2003. Microbial mercury transformation in anoxic freshwater sediments under iron-reducing and other electron-accepting conditions. Environmental Science \& Technology, 37: 2159-2165. PMID:12785521. doi:10.1021/es0262939.

Watras CJ, Morrison KA, Host JS, and Bloom NS. 1995a. Concentration of mercury species in relationship to other site-specific factors in the surface waters of northern Wisconsin lakes. Limnology and Oceanography, 40: 556-565. doi:10.4319/10.1995.40.3.0556.

Watras CJ, Bloom NS, Claas SA, Morrison KA, Gilmour CC, and Craig SR. 1995b. Methylmercury production in the anoxic hypolimnion of a dimictic seepage lake. Water, Air, and Soil Pollution, 80: 735-745. doi:10.1007/BF01189725.

Weiss-Penzias PS, Gay DA, Brigham ME, Parsons MT, Gustin MS, and ter Schure A. 2016. Trends in mercury wet deposition and mercury air concentrations across the US and Canada. Science of the Total Environment, 568: 546-556. doi:10.1016/j.scitotenv.2016.01.061.

Wiener JG, Krabbenhoft DP, Heinz GH, and Scheuhammer AM. 2003. Ecotoxicology of mercury. In Handbook of ecotoxicology. Edited by DJ Hoffman, BA Rattner, GA Burton Jr, and J Cairns. 2nd edition. CRC Press, Boca Raton, Florida. pp. 409-463.

Windham-Myers L, Marvin-Dipasquale M, Krabbenhoft DP, Agee J, Cox M, Heredia-Middleton P, et al. 2009. Experimental removal of wetland emergent vegetation leads to decreased methylmercury production in surface sediment. Journal of Geophysical Research, 114: G00C05. doi:10.1029/ 2008JG000815.

Windham-Myers L, Fleck JA, Ackerman JT, Marvin-DiPasquale M, Stricker CA, Heim WA, et al. 2014a. Mercury cycling in agricultural and managed wetlands: a synthesis of methylmercury production, hydrologic export, and bioaccumulation from an integrated field study. Science of the Total Environment, 484: 221-231. doi:10.1016/j.scitotenv.2014.01.033.

Windham-Myers L, Marvin-DiPasquale M, Kakouros E, Agee JL, Kieu LH, Stricker CA, et al. $2014 b$. Mercury cycling in agricultural and managed wetlands of California, USA: Seasonal influences of vegetation on mercury methylation, storage, and transport. Science of the Total Environment, 484: 308-318. doi:10.1016/j.scitotenv.2013.05.027.

Windham-Myers L, Marvin-DiPasquale M, Stricker CA, Agee JL, Kieu LH, and Kakouros E. 2014c. Mercury cycling in agricultural and managed wetlands of California, USA: experimental evidence of vegetation-driven changes in sediment biogeochemistry and methylmercury production. Science of the Total Environment, 484: 300-307. doi:10.1016/j.scitotenv.2013.05.028.

Xu X, Zhao J, Li Y, Fan Y, Zhu N, Gao Y, et al. 2016. Demethylation of methylmercury in growing rice plants: an evidence of self-detoxification. Environmental Pollution, 210: 113-120. PMID:26708765. doi:10.1016/j.envpol.2015.12.013.

Xun L, Campbell NER, and Rudd JWM. 1987. Measurements of specific rates of net methyl mercury production in the water column and surface sediments of acidified and circumneutral lakes. Canadian Journal of Fisheries and Aquatic Sciences, 44: 750-757. doi:10.1139/f87-091.

Yang Z, Fang W, Lu X, Sheng G-P, Graham DE, Liang L, et al. 2016a. Warming increases methylmercury production in an Arctic soil. Environmental Pollution, 214: 204-509. doi:10.1016/j. envpol.2016.04.069. 
Yang Z, Wullschleger SD, Liang L, Graham DE, and Gu B. 2016b. Effects of warming on the degradation and production of low-molecular-weight labile organic carbon in an Arctic tundra soil. Soil Biology and Biochemistry, 95: 202-211. doi:10.1016/j.soilbio.2015.12.022.

Yu RQ, Flanders JR, Mack EE, Turner R, Mirza MB, and Barkay T. 2012. Contribution of coexisting sulfate and iron reducing bacteria to methylmercury production in freshwater river sediments. Environmental Science \& Technology, 46: 2684-2691. PMID:22148328. doi:10.1021/es2033718.

Zhang Y, Jacob DJ, Horowitz HM, Chen L, Amos HM, Krabbenhoft DP, et al. 2016. Observed decrease in atmospheric mercury explained by global decline in anthropogenic emissions. Proceedings of the National Academy of Science, 113: 526-531. doi:10.1073/pnas.1516312113.

Zillioux EJ, Porcella DB, and Benoit JM. 1993. Mercury cycling and effects in freshwater wetland ecosystems. Environmental Toxicology and Chemistry, 12: 2245-2264. doi:10.1002/etc.5620121208.

Žižek S, Milačič R, Kovač N, Jaćimović R, Toman MJ, and Horvat M. 2011. Periphyton as a bioindicator of mercury pollution in a temperate torrential river ecosystem. Chemosphere, 85: 883-891. doi:10.1016/j.chemosphere.2011.06.110. 